\title{
In Vivo Tumorigenesis, Osteolytic Sarcomas, and Tumorigenic Cell Lines from Transgenic Mice Expressing the Human T-Lymphotropic Virus Type 1 (HTLV-1) Tax Viral Oncogene
}

Lisa G. Lanigan, ${ }^{* \dagger}$ Blake E. Hildreth, III, ${ }^{* \ddagger}$ Wessel P. Dirksen, ${ }^{*}$ Jessica K. Simmons, ${ }^{*}$ Chelsea K. Martin, ${ }^{* \S}$ Jillian L. Werbeck, ${ }^{*}$

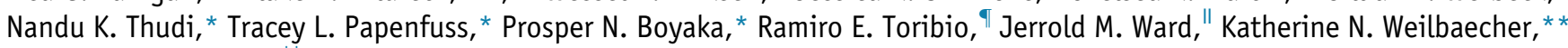
and Thomas J. Rosol*††

From the Department of Veterinary Biosciences, ${ }^{*}$ and the Department of Veterinary Clinical Sciences, ${ }^{\top}$ College of Veterinary Medicine, The Ohio State University, Columbus, Ohio; Tox Path Specialists, ${ }^{\dagger}$ a StageBio Company, Fredrick, Maryland; the Department of Pathology, ${ }^{\ddagger}$ University of Alabama at Birmingham, Birmingham, Alabama; Department of Pathology and Microbiology, ${ }^{\S}$ University of Prince Edward Island, Atlantic Veterinary College, Prince Edward Island, Canada; Global VetPathology," Montgomery Village, Maryland; the Division of Molecular Oncology, **Department of Medicine, Washington University School of Medicine, St. Louis, Missouri; and the Department of Biomedical Sciences, ${ }^{\dagger \dagger}$ Heritage College of Osteopathic Medicine, Ohio University, Athens, Ohio

\author{
Accepted for publication \\ October 13, 2020. \\ Address correspondence to \\ Thomas J. Rosol, D.V.M., \\ Ph.D., M.B.A., Department of \\ Biomedical Sciences, Heritage \\ College of Osteopathic Medi- \\ cine, Ohio University, Irvine \\ Hall 225, 57 Oxbow Trail, \\ Athens, OH 45701. E-mail: \\ rosolt@ohio.edu.
}

\begin{abstract}
Human T-lymphotropic virus type 1 (HTLV-1) causes adult T-cell leukemia, a disease commonly associated with hypercalcemia and osteolysis. There is no effective treatment for HTLV-1, and the osteolytic mechanisms are not fully understood. Mice expressing the HTLV-1 oncogene Tax, driven by the human granzyme B promoter $\left(\operatorname{Tax}^{+}\right)$, develop osteolytic tumors. To investigate the progression of the boneinvasive malignancies, wild-type, $\mathrm{Tax}^{+}$, and $\mathrm{Tax}^{+} /$interferon $-\gamma^{-/-}$mice were assessed using necropsy, histologic examination, IHC analysis, flow cytometry, and advanced imaging. $\operatorname{Tax}^{+}$and $\operatorname{Tax}^{+} /$interferon- $\gamma$ $-/-$ malignancies of the ear, tail, and foot comprised poorly differentiated, round to spindle-shaped cells with prominent neutrophilic infiltrates. Tail tumors originated from muscle, nerve, and/or tendon sheaths, with frequent invasion into adjacent bone. $\mathrm{F} 4 / 80^{+}$and anti-mouse $\mathrm{CD} 11 \mathrm{~b}$ (Mac-1) ${ }^{+}$histiocytic cells

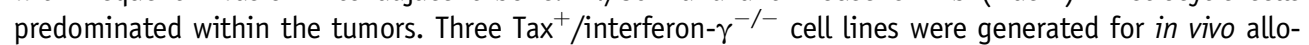
grafts, in vitro gene expression and bone resorption assays. Two cell lines were of monocyte/macrophage origin, and tumors formed in vivo in all three. Differences in Pthrp, Il6, Il1a, Il1b, and Csf3 expression in vitro were correlated with differences in in vivo plasma calcium levels, tumor growth, metastasis, and neutrophilic inflammation. $\operatorname{Tax}^{+}$mouse tumors were classified as bone-invasive histiocytic sarcomas. The cell lines are ideal for further examination of the role of HTLV-1 Tax in osteolytic tumor formation and the development of hypercalcemia and tumor-associated inflammation. (Am J Pathol 2021, 191: 335-352; https://doi.org/10.1016/j.ajpath.2020.10.014)
\end{abstract}

Adult T-cell leukemia/lymphoma (ATL), the sequela of human T-cell leukemia virus type 1 (HTLV-1) infection, is an aggressive lymphoproliferative malignancy of helper $\mathrm{T}$ lymphocytes from which hypercalcemia and osteolytic bone tumors develop. ${ }^{1-4}$ ATL occurs in $2 \%$ to $4 \%$ of HTLV-1 carriers and typically emerges after a 20 - to 40 -year latency. ${ }^{5}$ Bone invasion and resultant osteolysis are relatively uncommon in most lymphomas and leukemias; however, ATL in both humans and animal models is distinct in its associated high prevalence of osteolytic tumors and humoral hypercalcemia of malignancy (HHM) from elevated osteoclastic bone resorption. ${ }^{6-9}$

HTLV-1 expresses the viral oncogene Tax, which encodes the regulatory protein Tax and is located in the $\mathrm{pX}$

Supported by NIH/National Cancer Institute grants P01 CA100730 (T.J.R. and K.N.W.) and NIH/National Center for Research Resources grant T32 RR07073 (L.G.L.).

Disclosures: None declared. 
region of the HTLV-1 genome. Tax has multiple transcriptional trans-activating effects on multiple transcription factors, including cAMP response element-binding protein, $\mathrm{NF}-\kappa \mathrm{B}$, serum response factor, and the zinc-finger proteins specificity protein 1 and early growth response protein 1 , as well as trans-repressing effects. ${ }^{10-13}$ Tax also has posttranscriptional effects by: interacting with the cell cycle inhibitor p16, cyclin D3, and the mitotic arrest deficient protein MAD1 and activating kinases leading to 553 phosphorylation and inactivation. ${ }^{10,14,15}$ Several studies have demonstrated the transformation and immortalization of primary rodent cells by HTLV-1 Tax. ${ }^{16,17}$

Support for Tax acting as an oncoprotein comes from multiple transgenic mouse models. ${ }^{18-20}$ In several studies, the expression of Tax driven by the HTLV-1 long terminal repeat resulted in mesenchymal tumors, bone abnormalities, growth retardation, thymic atrophy, and inflammatory arthropathy. ${ }^{21-25}$ Mesenchymal tumors have also been associated with Tax expression driven by the Thy 1.2 promoter. ${ }^{21}$ Arthritis has been reported to occur when Tax was driven by the CD4 promoter. $^{26}$ In transgenic mice with HTLV-1 Tax driven by the human granzyme B promoter $\left(\mathrm{Tax}^{+}\right)$, hematopoietic malignancies, a mild increase in serum calcium, splenomegaly, and bone-invasive osteolytic lesions have been reported to develop, with features that resemble those in ATL patients. ${ }^{9,27}$ Tax expression has been associated with high levels of interferon (IFN)- $\gamma$ in HTLV-1-infected $\mathrm{CD}^{+}{ }^{+} \mathrm{T}$ cells and $\mathrm{Tax}^{+}$mice. When $\mathrm{Tax}^{+}$mice were crossed with global IFN- $\gamma-$ knockout mice $\left(\mathrm{Tax}^{+} / \mathrm{IFN}-\gamma^{-1-}\right)$, accelerated tumorigenesis and death occurred. ${ }^{28,29}$ From these findings, it is believed that IFN- $\gamma$ may play a role in the immune resistance to tumor development.

In the present study, $\operatorname{Tax}^{+}$and $\mathrm{Tax}^{+} / \mathrm{IFN}-\gamma^{-1-}$ mice developed widespread multifocal, bone-invasive histiocytic sarcomas (HSs). These lesions were originally described as lymphocytic tumors that arose in the ears, tails, and limbs, with some features of natural killer cells. ${ }^{9,27}$ Since then, it has been reported that peripheral HSs of the ears, tail, and limbs develop in these mice. ${ }^{30-32}$ Histologic examination, immunohistochemistry (IHC) analysis, flow cytometry, and advanced imaging (digital radiography and micro -computed tomography) were performed for a better understanding of tumor histogenesis, development, and progression. Cell lines derived from peripheral tumors of $\mathrm{Tax}^{+} /$ IFN- $\gamma^{-1-}$ mice were characterized by: i) flow cytometry; ii) in vivo and in vitro studies exploring their tumorigenic, metastatic, and osteolytic potential; and iii) gene expression profiling, for a further understanding of the pathogenesis of HTLV-1 Tax-induced malignancies.

\section{Materials and Methods}

\section{Mice}

The use of wild-type (WT) mice, mice with HTLV-1 $\mathrm{Tax}^{+},{ }^{9,27}$ and $\mathrm{Tax}^{+} / \mathrm{IFN}-\gamma^{-1-}$ mice ${ }^{28,29}$ on a C57BL/6.SJL background was approved by the institutional animal care and use committee at The Ohio State University (Columbus, $\mathrm{OH})$. Mice were gifted from the laboratories of Drs. Katherine N. Weilbaecher and Lee Ratner at Washington University (St. Louis, MO). Genotypes were confirmed by genomic DNA PCR (DNAEasy Kit; Qiagen, Valencia, CA). Mice were monitored for tumor development or illness (ruffled coat, dyspnea, or weight loss). Those reaching a defined time point or early removal criteria (ERC) with a tumor diameter of $>15 \mathrm{~mm}$ or illness were euthanized.

\section{Necropsy and Histologic Examination}

After postmortem evaluation, lesions were recorded and tissues fixed in $10 \%$ neutral-buffered formalin for 48 to 72 hours at $4{ }^{\circ} \mathrm{C}$ followed by $70 \%$ ethanol. Bones were then decalcified in 10\% EDTA (pH 7.4) for 10 to 14 days. Soft tissues and bones were subsequently paraffin embedded, sectioned at 4 $\mu \mathrm{m}$, and stained with hematoxylin and eosin. Tissues and tumors from mice with tumor cell line allografts (Tax-Induced Malignant Cell Line Allografts) were treated in the same manner. All slides used for histologic and IHC analyses were digitally imaged using an Aperio ScanScope slide scanner (Leica Biosystems, Buffalo Grove, IL). All magnifications reported in the figure legends indicate the objective setting used in Aperio and are approximate.

\section{IHC Analysis}

Select tissues were stained with the following primary antibodies: CD3 (rabbit anti-human, 1:50), CD20 (rabbit, 1:200), cytokeratin (AE1/AE3) (rat anti-mouse, 1:250), keratin 8 (rat anti-mouse, 1:50), S-100 (rabbit, 1:1000) [all from Agilent Technologies (formerly Dako Cytomation), Santa Clara, CA]; F4/80 [rat anti-mouse, 1:100; Bio-Rad (formerly AbD Serotec), Hercules, CA]; and HTLV-1 Tax (rabbit, 1:1000; made at The Ohio State University). This anti-Tax antibody was previously shown to be specific for human $\operatorname{Tax}^{33}$

\section{Flow Cytometry on Peripheral Tumors and Spleens}

Cells were isolated from all genetic groups using a $70 \mu \mathrm{mol} /$ L nylon mesh, washed in RPMI, and resuspended in RPMI containing $10 \%$ fetal bovine serum. Half of the cells were stimulated for 1 hour at $37^{\circ} \mathrm{C}$ with $50 \mathrm{ng} / \mathrm{mL}$ phorbolmyristate-acetate and $750 \mathrm{ng} / \mathrm{mL}$ ionomycin. Cytokine secretion was inhibited with $2 \mu \mathrm{mol} / \mathrm{L}$ GolgiStop (BD Biosciences, San Jose, CA) for 4 hours at $37^{\circ} \mathrm{C}$. All cells were then washed and resuspended in fluorescence-activated cell sorting buffer [phosphate-buffered saline; Invitrogen (part of Thermo Fisher Scientific), Carlsbad, CA] with 2\% fetal bovine serum, $0.01 \% \mathrm{NaN}_{3}$ ). For extracellular staining, cells were incubated for 30 minutes at $4^{\circ} \mathrm{C}$ with a combination of anti-mouse CD11b (Mac-1), CD8, B220 (CD45R), $\mathrm{CD} 3 \mathrm{e}$, and $\mathrm{CD} 4$ (BD Biosciences) antibodies. For 
intracellular staining, cells were fixed with Cytofix/Cytoperm for 20 minutes at $4^{\circ} \mathrm{C}$ and permeabilized by washing three times with 1X PermWash (BD Biosciences) before 30 minutes of incubation at $4^{\circ} \mathrm{C}$ with anti-human granzyme $\mathrm{B}$ antibody (BD Biosciences). Finally, cells were washed in fluorescence-activated cell sorting buffer and analyzed (Accuri C6; BD Biosciences).

\section{Complete Blood and Differential Counts}

Blood was obtained postmortem by cardiocentesis from eight $\mathrm{Tax}^{+}$and nine WT 12-month-old mice. Complete blood and white blood cell differential counts were performed (Forcyte Autosampler 10; Oxford Science, Inc., Oxford, CT). Blood smears were evaluated for circulating tumor cells by light microscopy.

\section{Digital Radiography}

Images from three mice randomly selected from each genotype at 3, 6, and 12 months were obtained at 40 kilovoltage peak for 30 seconds (whole mice) and 32 kilovoltage peak for 11 seconds (tails) (LX-60 Digital Radiography System; Faxitron Bioptics, Tucson, AZ).

\section{Microcomputed Tomography}

Tail images were generated in 400 projections over 360 degrees at 100 kilovoltage peak, 200 milliampere, 1250 millisecond exposure, Bin 2, with a medium-high system magnification and $19.4 \mu \mathrm{m}$ resolution (Inveon Preclinical CT; Siemens AG, Munich, Germany). Data was threedimensionally reconstructed (Cobra; Exxim Computing Corp., Pleasanton, CA) and vertebral lengths measured (Inveon Research Workplace 3-D Image software version 3.0; Siemens). Metaphyseal volumes of interest were defined as $20 \%$ of the vertebral length adjacent to the physis. Bone volume fraction (bone volume/total volume), bone mineral density, and overall density were determined for the two most lytic vertebrae per mouse, with the mean calculated to give a single-mouse value. Segmentation thresholds were kept constant. Samples were evaluated in a blinded manner and in a randomized order using predefined randomization tables by B.E.H.

\section{Derivation and Flow Cytometric Characterization of Immortalized $\operatorname{Tax}^{+}$Tumor Cell Lines}

Three cell lines were generated from spontaneous $\mathrm{Tax}^{+} /$ IFN- $\gamma^{-1-}$ tumors: i) T94, tail mass, 6-month-old female; ii) 501, hind limb osteolytic mass, 6-month-old male; and iii) Tom3, mixed osteolytic/osteoblastic mass invading the radius and ulna, 7-month-old male. Tumors were minced in Dulbecco's Modified Eagle's medium/F12 media (Invitrogen) with $25 \mu \mathrm{g} / \mathrm{mL}$ Plasmocin (Invivogen, San Diego, CA) and 10\% fetal bovine serum (Invitrogen). Tumor pieces were washed in medium (three times) and incubated for 48 to 72 hours to allow individual cells to adhere to tissue culture plastic. After 2 weeks in Plasmocin-containing medium, adherent cells were grown in Dulbecco's Modified Eagle's medium/F12 with $100 \mathrm{U} / \mathrm{mL}$ penicillin, $100 \mu \mathrm{g} / \mathrm{mL}$ streptomycin (penicillin-streptomycin), and $10 \%$ fetal bovine serum. Initial s.c. engraftment of T94 cells in nude mice resulted in small, slow-growing tumors; therefore, cells from the fastest-growing tumor were rederived for the generation of a new cell line selected for in vivo growth (T94S). At 70\% confluence, cells were washed, resuspended in fluorescence-activated cell sorting buffer, and incubated for 30 minutes at $4^{\circ} \mathrm{C}$ with anti-mouse $\mathrm{CD} 11 \mathrm{~b}$ (Mac-1), CD11c, major histocompatibility complex (MHC)-II, Ly6C, and Ly6G (BD Biosciences) antibodies. Cells were then washed in fluorescence-activated cell sorting buffer and analyzed (Accuri C6; BD Biosciences).

\section{Tax-Induced Malignant Cell Line Allografts}

S.c. $(n=3)$, intratibial $(n=3)$, and bone-adjacent $(n=2)$ injections of each cell line were performed in 6-week-old athymic $n u / n u$ nude mice (Harlan Laboratories, Inc., Indianapolis, IN) under isoflurane-in-oxygen anesthesia. S.c. tumors were generated by injecting $1 \times 10^{6}$ cells in $100 \mu \mathrm{L}$ of phosphate-buffered saline into the s.c. tissue over the right scapula with a 25 -gauge needle. Intratibial tumors were made by injecting $2 \times 10^{5}$ cells in $20 \mu \mathrm{L}$ of phosphatebuffered saline into the marrow cavity of the right tibia with a 27-gauge needle. Bone-adjacent tumors were generated by injecting $5 \times 10^{5}$ cells in $50 \mu \mathrm{L}$ of phosphate-buffered saline into the lateral right hindlimb adjacent to the middiaphysis of the tibia with a 25-gauge needle. Mice were observed twice weekly for tumor growth or lameness (intratibial and bone adjacent). Mice were euthanized when tumor sizes exceeded $2 \mathrm{~cm}$ in diameter or were ulcerated, or if there was persistent lameness.

\section{Calvarial Co-Culture}

Conditioned media $(\mathrm{CM})$ was produced by culturing each cell line at 70\% confluence in Dulbecco's Modified Eagles's medium/F12 with $0.1 \%$ bovine serum albumin (SigmaAldrich, St. Louis, MO) and penicillin-streptomycin for 72 hours. Media were collected, centrifuged at $80 \times \mathrm{g}$ for 5 minutes for the removal of cellular debris, and stored at $-20^{\circ} \mathrm{C}$. BALB/c pups of 4 to 6 days of age were euthanized, and two calvarial bone disks, including the frontal and parietal bones, were collected from each mouse using a 3.5-mm-diameter skin-biopsy punch. Calvaria were washed in phosphate-buffered saline and three times in BGJb media (Invitrogen), 0.1\% radioimmunoassay-grade bovine serum albumin (Sigma-Aldrich) and $100 \mu \mathrm{g} / \mathrm{mL}$ Normocin (Invivogen). After overnight incubation at $37^{\circ} \mathrm{C}$ and $5 \% \mathrm{CO}_{2}$, six paired disks were randomized to each $\mathrm{CM}$ group and a non-CM control group. Disks were cultured for 
6 days in $50 \% \mathrm{CM}$ and $50 \%$ BGJb with $0.1 \%$ bovine serum albumin and $100 \mu \mathrm{g} / \mathrm{mL}$ Normocin. On day 6 , disks were fixed and stained for tartrate-resistant acid phosphatase (TRAP) activity (Leukocyte Acid Phosphatase Kit 387A; Sigma-Aldrich). Calvaria were mounted on glass slides, imaged, and analyzed for total bone area and resorptive perimeter using Image Pro Plus image-analysis software version 6.0 (Media Cybernetics, Inc., Bethesda, MD). Media from the co-cultures were collected and centrifuged at $80 \times \mathrm{x} \mathrm{f}$ for 5 minutes, and total calcium concentrations were determined (Quanti-Chrom colorimetric assay; BioAssay Systems, Hayward, CA).

\section{Plasma Calcium Concentrations}

Heparinized blood was collected after euthanasia from five, 12-month-old mice from each genetic group (WT, Tax ${ }^{+}$, $\mathrm{Tax}^{+} / \mathrm{IFN}-\gamma^{-/-}$) and allografted mice. Plasma calcium concentrations were measured using a calcium assay kit (BioAssay Systems). Plasma calcium concentrations of $>13$ $\mathrm{mg} / \mathrm{dL}$ indicated HHM. ${ }^{34,35}$

\section{Real-Time RT-PCR}

RNA was isolated from 70\% confluent T94, 501, and Tom3 cells grown in triplicate and cDNA made with $0.5 \mu \mathrm{g}$ of RNA (SuperScript II; Invitrogen). Real-time RT-PCR analysis for genes known to be involved in osteolysis and the NF- $\mathrm{BB}$ pathway was performed (QuantiTect SYBR Green PCR Kit; Qiagen Inc.) with mouse-specific primers (listed $5^{\prime}$ to $3^{\prime}$ ): Ppia F 5'-CGCGTCTCCTTCGAGCTGTTTG-3', R 5'-TGTAAAGTCACCACCCTGGCACAT- $3^{\prime}$; Ubc F 5'-CGTCGAGCCCAGTGTTACCACCAAGAAGG-3'，R 5'-CCCCCATCACACCCAAGAACAAGCACAAG-3'; Gapdh F 5'-ATGACATCAAGAAGGTGGTG-3', R 5'-CATACCAGGAAATGAGCTTG- ${ }^{\prime}$; Actb F 5'-ATGAGCTGCCTGACGGCCAGGTCATC-3', R 5'-TGGTACCACCAGACAGCACTGTGTTG3'; human Tax F 5'-CCGCCGATCCCAAAGAAA-3', R 5'-CCGAACATAGTCCCCCAGA-3'; Pthrp F 5'-AGTGTCCTGGTATTCCTGCTC-3'， R 5'-ATGCAGTAGCTGATGTTCAGACAC-3'; Rankl F 5'-ACACCTCACCATCAATGCT3', R 5'-CTTAACGTCATGTTAGAGATCTTGG-3'; Opg F 5'-AGCTGCTGAAGCTGTGGAA-3', R 5'-TCGAGTGGCCGAGAT-3'; Il6 F 5'-TCCAGAAACCGCTATGAAGTT-CCT
CT-3', R 5'-AGGCCGTGGTTGTCACCAGC-3'; Rank F 5'GCTGGCTACCACTGGAACTC-3'， R $5^{\prime}$-TGTGCACAC CGTATCCTTGT-3'; Csf3 (Csfg) F 5'-GCGC-ATGAAGCTAATGGCCCTG-3'， R 5'-AGGGGAACGG-CCTCTCGTCC-3'; Illa $\mathrm{F}$ 5'-CCAGCCCGTGTTGCTGAAGGAG-3', R $5^{\prime}$-ATAGAGGGCAGTCCCCGTGCC-3'; and $I l 1 b$ F $5^{\prime}$-GACGGACCCCAAAAGATGAAGGGC-3'， R 5'-CTGCCACAGCTTCTCCACAGCC-3'. Expression was normalized to $A c t b$, Ppia, Ubc, and Gapdh by the calculation of geometric means and reporting relative to the lowest-expressing cell line. ${ }^{36}$

\section{Statistical Analysis}

Results are shown as means \pm SD. Data were analyzed with the $t$-test or 1-way analysis of variance and Bonferroni post hoc test [JMP software version 9 (SAS Institute Inc., Cary, NC) and Prism software version 8 (GraphPad Software, San Diego, CA)]. $P<0.05$ was considered statistically significant. Sample size was not determined statistically prior to experimentation.

\section{Results}

Mice Expressing HTLV-1 Tax Developed Histiocytic Malignancies around the Tendon Sheaths and Perichondrium and Splenomegaly due to Myelopoiesis

Tumors from the three genetic groups-WT, $\mathrm{Tax}^{+}$, and $\mathrm{Tax}^{+} / \mathrm{IFN}-\gamma^{-1-}$-were characterized over time (Table 1). Mice meeting ERC due to ulcerative dermatitis, a common C57BL/6 lesion, were excluded. Soft-tissue masses were visible on the ears, nose, tail, and feet of the $\mathrm{Tax}^{+} / \mathrm{IFN}-\gamma^{-1-}$ mice at 3 months, and the $\mathrm{Tax}^{+} / \mathrm{IFN}-\gamma^{-1-}$ mice met ERC at 6 months due to ulceration and lameness. In contrast, the $\operatorname{Tax}^{+}$ mice did not have external evidence of tumors until 6 months, and did not meet ERC until 15 months. In the $\mathrm{Tax}^{+}$and $\mathrm{Tax}^{+} /$ IFN- $\gamma^{-1-}$ mice, ERC also resulted from splenomegaly (30 to 50 times WT volume), causing dyspnea and loss of body condition (Figure 1A). Histologic evaluation of 12- and 15month-old mice included brain, heart, lungs, liver, kidneys, spleen, pancreas, and gastrointestinal and reproductive tracts. There were no significant lesions in any soft-tissue organ except the spleen. When compared to spleens from the WT mice (Figure 1, B and C), the splenomegaly

Table 1 Summary of Gross Pathologic Findings

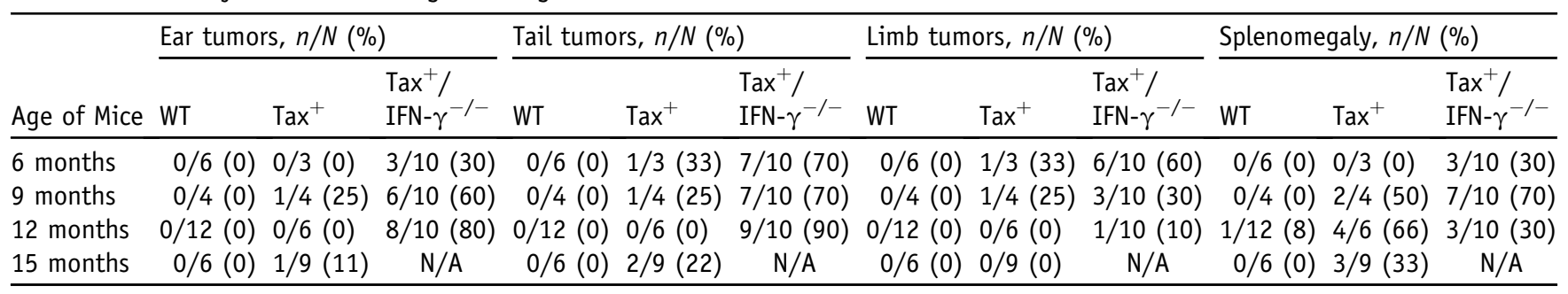

N/A, not available. 

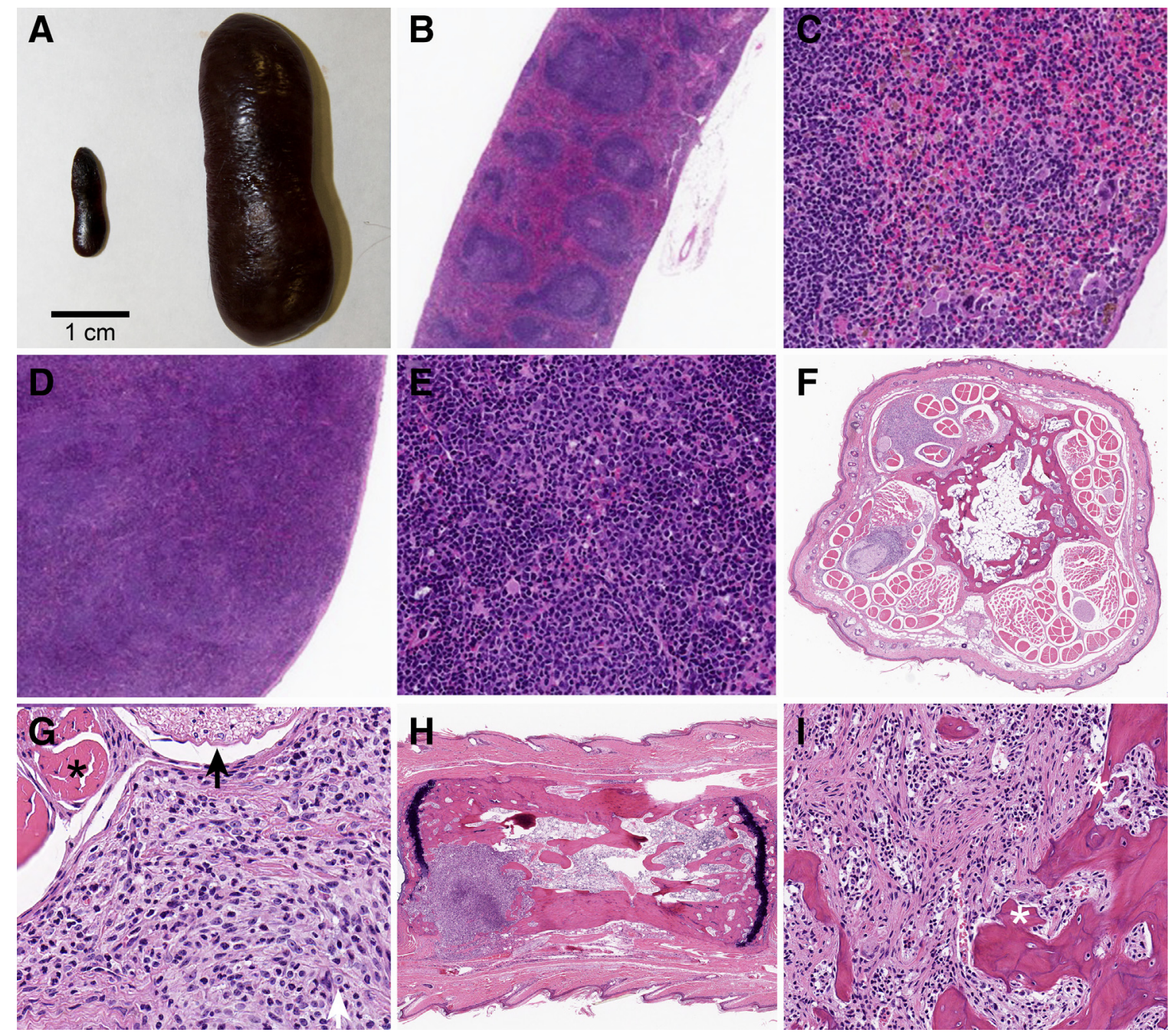

Figure 1 Mice expressing HTLV-1 Tax developed histiocytic malignancies around the tendon sheaths and perichondrium and splenomegaly due to myelopoiesis. A: Marked splenomegaly in a 12-month-old Tax ${ }^{+}$mouse (right), compared to wild-type (WT) (left), a common feature in 12- to 15-month-old Tax ${ }^{+}$ and Tax ${ }^{+} /$IFN $-\gamma^{-1-}$ mice. B and C: Low (B) and high (C) magnification images of a WT spleen. D and E: Low (D) and high (E) magnification images of a Tax ${ }^{+}$ spleen reveal that the splenomegaly observed in $\operatorname{Tax}^{+}$mice is due to marked myelopoiesis with increased megakaryocytes. F: Multifocal areas of histiocyte proliferation surrounding tendons and nerves adjacent to the caudal vertebrae in the tail of a 6 -month-old, male, $\operatorname{Tax}^{+} / \mathrm{IFN}-\gamma^{-1-}$ mouse (2× magnification).

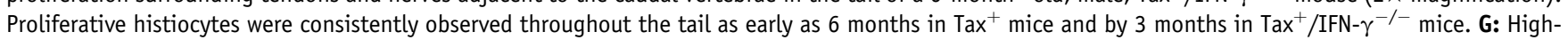
magnification image of proliferative histiocytes surrounding tendon (asterisk) and nerve (black arrow). Cells are a mixture of proliferative pleomorphic histiocytes (white arrow) with a myxomatous stroma and well-differentiated neutrophils. H: Histiocytic tumor with invasion into the caudal vertebral metaphysis and bone lysis in a 12 -month-old, male, $\operatorname{Tax}^{+} / \mathrm{IFN}-\gamma^{-/-}$mouse. Despite neoplastic cells surrounding tendon along the vertebrae, the metaphysis is the typical site of bone invasion. I: After invading the bone marrow, histiocytic tumor cells become more spindle-shaped, with a collagenous extracellular matrix and osteoclastic bone resorption (asterisk). Scale bar $=1 \mathrm{~cm}$. Original magnification: $\times 2(\mathbf{B}, \mathbf{D}, \mathbf{F}$, and $\mathbf{H}) ; \times 10(\mathbf{C}, \mathbf{E}$, and $\mathbf{I}) ; \times 20(\mathbf{G})$.

observed in the $\mathrm{Tax}^{+}$and $\mathrm{Tax}^{+} / \mathrm{IFN}-\gamma^{-1-}$ mice resulted from marked myelopoiesis and increased megakaryocytes (Figure 1, D and E).

Multiple bones-skull, radius, ulna, tibia/fibula, metatarsals, and metacarpals-were examined histologically in the 12- and 15-month-old $\mathrm{Tax}^{+}, \mathrm{Tax}^{+} / \mathrm{IFN}-\gamma^{-1-}$, and WT mice, and multiple sections of tail vertebrae at all time points. Ear pinna tumors were also evaluated and had cellular infiltrates surrounding the cartilage of the pinna, with histologic and IHC features similar to those of the bone tumors. Tail tumors were identical to those present in the appendicular skeleton; however, the tail was chosen for further histologic evaluation at multiple time points for uniformity of sectioning and for comparing histologic examination findings with those from advanced imaging. Although tumors were not observed grossly in all $\mathrm{Tax}^{+}$and $\mathrm{Tax}^{+} /$IFN $-\gamma^{-1-}$ mice, all tail sections had some degree of cellular proliferation around the tendon and nerve sheaths (Figure 1F). Cellular infiltrates in the $\mathrm{Tax}^{+}$mice at 6 and 9 months were mild and multifocal, increasing in severity with age. Evidence of bone invasion was not typically present in early tumors. The cellular infiltrates were significantly worse in the $\mathrm{Tax}^{+} / \mathrm{IFN}-\gamma^{-1-}$ mice when compared to those in the $\mathrm{Tax}^{+}$mice. Peritendinous/perineural tumors 
consisted of histiocytic cells that were large and round to spindle-shaped, with oval to round nuclei and coarsely stippled chromatin (Figure 1G). Their extracellular matrix consisted of a lightly basophilic granular material, interpreted as mucin. About half of the cells in the tumors were non-neoplastic, well-differentiated, mature neutrophils (Figure 1G). Histiocytic tumors were consistently present in the soft tissue adjacent to the metaphysis, frequently invaded bone, and were associated with osteoclastic bone resorption. This was especially the case with advanced tumors in the $\operatorname{Tax}^{+}$mice at 12 months and in the $\mathrm{Tax}^{+} / \mathrm{IFN}$ $\gamma^{-l-}$ mice at 9 months of age, wherein the latter bone loss was more severe, occurred at an earlier time point, and advanced to greater bone lysis by 12 months (Figure 1, H and I). Tumor cells within the bone marrow were more spindle shaped, with a collagenous matrix (Figure 1I). The site of bone invasion was consistent in the cutback zone of the metaphysis in the $\mathrm{Tax}^{+}$and $\mathrm{Tax}^{+} / \mathrm{IFN}-\gamma^{-1-}$ mice.

In addition to osteolytic tumors, distinct regions of metaphyseal osteosclerosis were frequent in the vertebrae and appendicular bones of the $\mathrm{Tax}^{+} / \mathrm{IFN}-\gamma^{-l-}$ mice. The increased trabecular bone was independent of the histiocytic tumors and associated bone lysis. There was an increase in both trabecular number and thickness in the regions of medullary osteosclerosis. Frequent cement lines and regions of retained cartilage suggested increased abnormal bone modeling and remodeling. Osteosclerosis was present only in the $\mathrm{Tax}^{+} / \mathrm{IFN}-\gamma^{-1-}$ and not in the $\mathrm{Tax}^{+}$mice. In vivo, IFN- $\gamma$ has both direct anti-osteoclastogenic and indirect proosteoclastogenic effects. However, in inflammatory states, the net balance leads to IFN- $\gamma$ stimulating bone resorption. ${ }^{37}$ The increased bone volume was due to decreased bone resorption, which was due to decreased IFN- $\gamma$ in the $\mathrm{Tax}^{+} /$ IFN $-\gamma^{-1-}$ mice but not in the $\mathrm{Tax}^{+}$mice, with HS invasion and associated inflammatory infiltrate. The Tax ${ }^{+}$and $\mathrm{Tax}^{+} /$ IFN $-\gamma^{-l-}$ mice also had increased bone marrow cellularity compared to that in the WT mice, but the hematopoietic cells were in their normal expected proportions.

IHC analysis of the macrophage-specific antigen, F4/80, and HTLV-1 Tax were consistently positive in the histiocytic tumor cells. All other IHC staining performed on the tumors - CD3 for normal and neoplastic T cells, CD20 for normal and neoplastic B cells, pancytokeratin (AE1/AE3) for high- and low-molecular-weight keratins in epithelia, keratin 8 for nonsquamous/ductal epithelium, and S-100 for nonsquamous/ductal epithelium-were negative. As expected, F4/80 staining was largely restricted to the cell membrane, with a small amount of cytoplasmic staining (Figure 2, A and B). HTLV-1 Tax staining was diffusely cytoplasmic and weakly nuclear, with poorly defined cell margins (Figure 2, C and D). The histiocytic phenotype of the tumor cells was confirmed by flow cytometry using a tumor from one mouse from each genetic group, which demonstrated that the majority of the tumor cells were positive for Mac-1 (CD11b), a marker for macrophages/ monocytes and DCs (Figure 3A). Intracellular granzyme B expression was also observed in $\mathrm{Mac}^{+}{ }^{+}$cells, and co-expression was increased after phorbol-myristate-acetate and ionomycin treatment (Figure 3B). The increase in granzyme $\mathrm{B}$ expression was not seen in $\mathrm{B}$ and $\mathrm{T}$ lymphocytes (Figure 3B). In summary, tumors were histiocytic sarcomas, of which the malignant histiocytes expressed both Tax and granzyme B.

\section{Mice Expressing Tax Had Peripheral Leukocytosis and Mild Anemia}

There were no identifiable circulating tumor cells in the blood smears of the $\mathrm{Tax}^{+}$mice. The 12-month-old $\mathrm{Tax}^{+}$ mice had significantly increased total leukocytes $(21.3 \pm 4.0$ versus $11.1 \pm 1.9, P=0.03)$, neutrophils $(4.9 \pm 1.1$ versus $2.3 \pm 0.4, P=0.04)$, and lymphocytes $(13.9 \pm 2.5$ versus $7.5 \pm 1.4, P=0.04)$ compared to those in the WT mice. There were trends toward greater circulating monocytes $(2.1 \pm 0.5$ versus $1.1 \pm 0.2, P=0.06)$ and a lower hematocrit $(31.6 \pm 1.2$ versus $35.3 \pm 1.7, P=0.10)$ in the $\mathrm{Tax}^{+}$mice. Therefore, the 1.9-fold increase in peripheral leukocyte number in the 12-month-old $\mathrm{Tax}^{+}$mice may have resulted from a 2.1-fold increase in neutrophils and a 1.9-fold increase in both lymphocytes and monocytes. In summary, the increase in total white blood cell number was likely due to both inflammation (neutrophils and lymphocytes) and increased circulating monocytes.

\section{Bone Invasion and Osteolysis Were Present in $\mathrm{Tax}^{+}$ Transgenic Mice}

Radiography and micro computed tomography were used for confirming tumor-associated bone loss, characterized by increased osteolysis and radiolucency, in the $\mathrm{Tax}^{+}$mice (Figure 4). As on histologic examination, bone loss was more severe in the $\mathrm{Tax}^{+} / \mathrm{IFN}-\gamma^{-1-}$ mice, which occurred at an earlier time point and advanced to greater bone lysis by 12 months. The typical area of bone invasion by the HS was the cortex, adjacent to the metaphysis (near the cutback zone). There was a significant decrease in bone volume fraction in the $\mathrm{Tax}^{+}$compared to the WT mice on micro computed tomography at sites of histiocytic tumor invasion $(64.2 \pm 9.8$ versus $86.1 \pm 9.3 \%$, $P=0.048)$. The $\mathrm{Tax}^{+}$mice also had significantly lower values of bone mineral density $(1274 \pm 15.4$ versus $1395 \pm 36.3 \mathrm{mg} /$ $\left.\mathrm{cm}^{3}, P=0.006\right)$ and overall density $(1183 \pm 38.8$ versus $\left.1346 \pm 66.0 \mathrm{mg} / \mathrm{cm}^{3}, P=0.021\right)$ compared to those in the WT mice. These osteolytic lesions are consistent with findings from previous work from the authors using these $\operatorname{Tax}^{+}$and $\operatorname{Tax}^{+} /$ IFN $-\gamma^{-1-}$ mice, in which there was an increase in the number of $\mathrm{TRAP}^{+}$osteoclasts adjacent to tail vertebral tumors in the $\mathrm{Tax}^{+}$ mice. ${ }^{9,38}$ In addition, the osteoclast number and perimeter (both per bone surface) were greater in the $\mathrm{Tax}^{+} / \mathrm{IFN}-\gamma^{-/-}$mice compared to those in the $\mathrm{Tax}^{+}$mice in a previous report. ${ }^{29}$ However, 12-month-old tumor-bearing $\mathrm{Tax}^{+}$mice had decreased in vivo bone formation by calcein-double labeling (Supplemental Figure S1A), and reduced osteoblast progenitors 

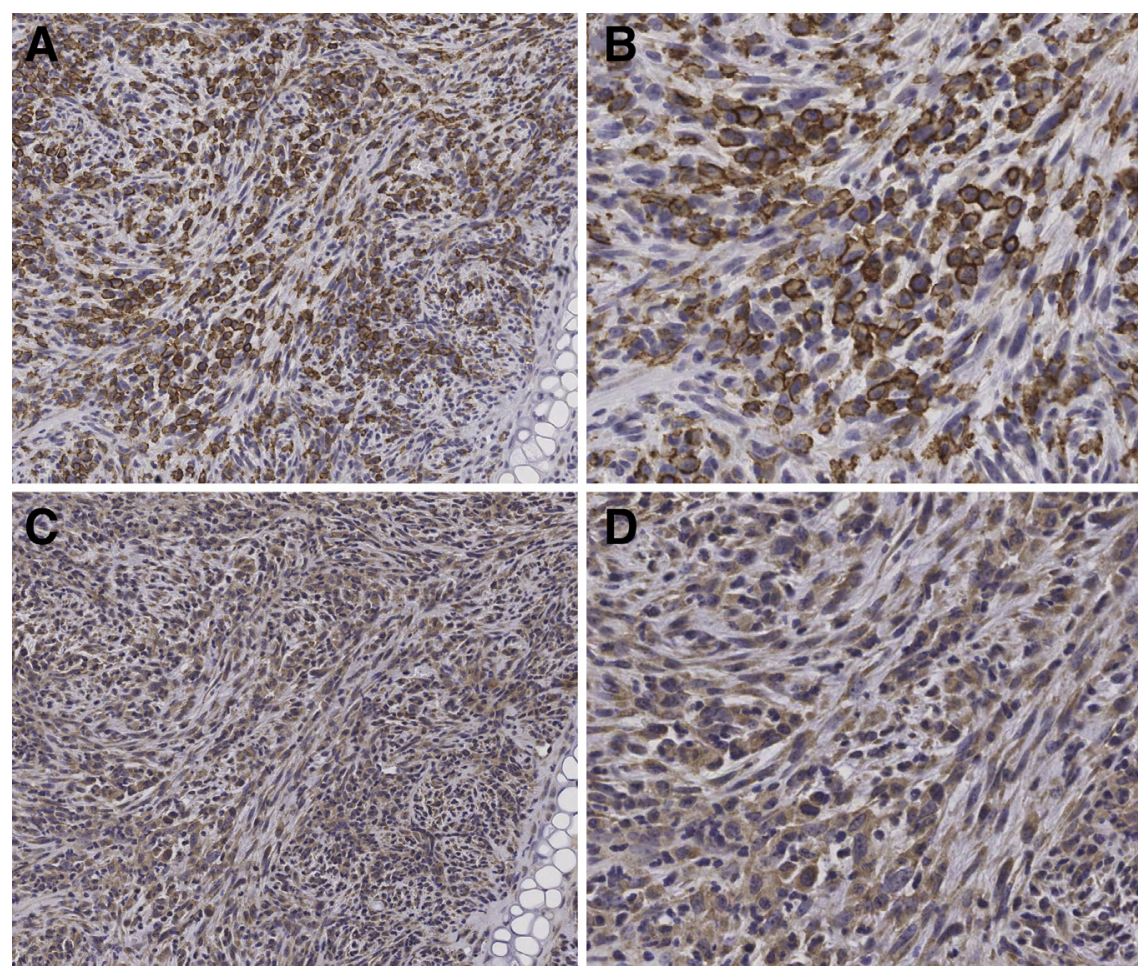

Figure 2 Neoplastic HTLV-1 $\mathrm{Tax}^{+}$cells are F4/ $80^{+}$, indicating a histiocytic malignancy. A: IHC analysis of a tumor along the ear pinna cartilage of a 6-month-old $\mathrm{Tax}^{+} / \mathrm{IFN}-\gamma^{-/-}$mouse for the macrophage-specific antigen F4/80. Neoplastic cells are consistently positive for $F 4 / 80$. The round histiocytic tumor cells have more intense staining compared to the spindle-shaped tumor cells. B: Magnification (400x) with Aperio (Leica Biosystems) of F4/80 staining in Figure 2A. C: IHC analysis of HTLV-1 Tax reveals widespread cytoplasmic labelling with less-frequent nuclear staining in the neoplastic cells (100 $\times$ magnification). D: Magnification (400x) with Aperio of HTLV-1 Tax staining in Figure 2 C. Original magnification: $\times 100$ (A and $\mathbf{C})$.

in the mineralizing condition, but not fibroblast progenitors in the basal condition (Supplemental Figure S1B), when compared to those in the WT mice. Osteosclerosis in the $\mathrm{Tax}^{+} /$ IFN- $\gamma^{-1-}$ mice precluded meaningful comparison, because despite osteolysis at regions of HS invasion, the concurrent osteosclerosis in other parts of the metaphysis resulted in a greater bone volume fraction in the $\mathrm{Tax}^{+} / \mathrm{IFN}-\gamma^{-1-}$ mice $(83.7 \% \pm 2.1 \%)$ than in the $\operatorname{Tax}^{+}$mice $(P<0.05)$, with no difference between the $\mathrm{Tax}^{+} / \mathrm{IFN}-\gamma^{-1-}$ and the WT mice (threegroup comparison by one-way analysis of variance). Despite multifocal tumor-associated bone lysis in both transgenic mice and a significant decrease in bone volume fraction in the $\mathrm{Tax}^{+}$
A

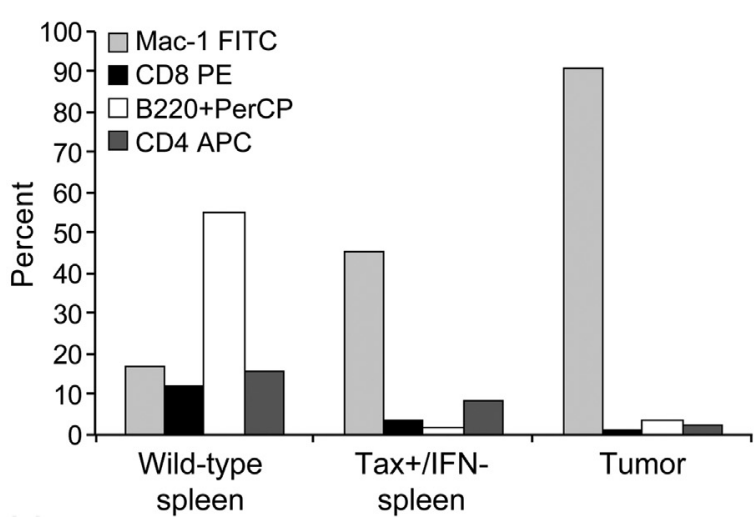

B
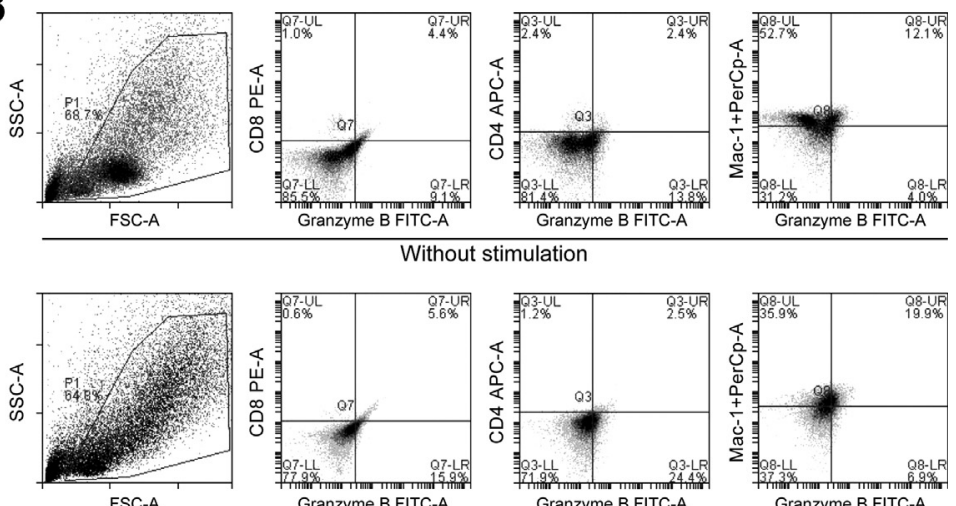

Granzyme B FITCA

Granzyme B FITC-A

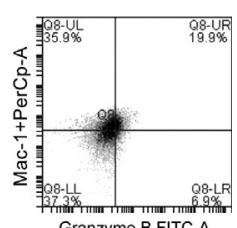

Granzyme B FITC

With stimulation Figure 3 The histiocytic phenotype of the tumor cells is confirmed by flow cytometry, and their expression of macrophage/monocyte markers and granzyme B
increases with inflammation. A: The predominant cell type in the spleen of a wild-type (WT) mouse was B cells. The majority of cells in the tail tumor of Tax ${ }^{+}$mice were Mac-1 $\mathrm{CD}_{11} \mathrm{~b}^{+}$with few $\mathrm{B}_{220^{+}} \mathrm{B}$ lymphocytes or $\mathrm{CD}^{+}$or $\mathrm{CD} 8^{+} \mathrm{T}$ lymphocytes. The Mac- $1 \mathrm{CD} 11 \mathrm{~b}^{+}$labeling demonstrated that the predominant neoplastic cell population in the tail tumors was macrophage/monocyte in origin. The spleen from Tax ${ }^{+}$mice had increased Mac- $1^{+}$cells with few B and T cells. Note the majority of the splenic cells (myelopoietic cells) and the tumor neutrophils in the Tax ${ }^{+}$mice were not stained by the antibody panel. B: Co-expression of granzyme B and Mac- 1 in the tumor cells was increased from $12.1 \%$ in unstimulated cells (top row) to $19.9 \%$ after phorbol-myristate-acetate and ionomycin stimulation (bottom row). Co-expression demonstrates increased granzyme B in activated histiocytes, but not in B and T lymphocytes. Due to their overall low cellularity, findings are from one tumor from each genetic group. APC, allophycocyanin; FITC, fluorescein isothiocyanate; FSC, forward scatter; FSC-A, forward scatter area; PE, phosphatidylethanolamine; PE-A, phosphatidylethanolamine-area; PerCP, peridinin chlorophyll protein; SSC-A, side scatter light area. 


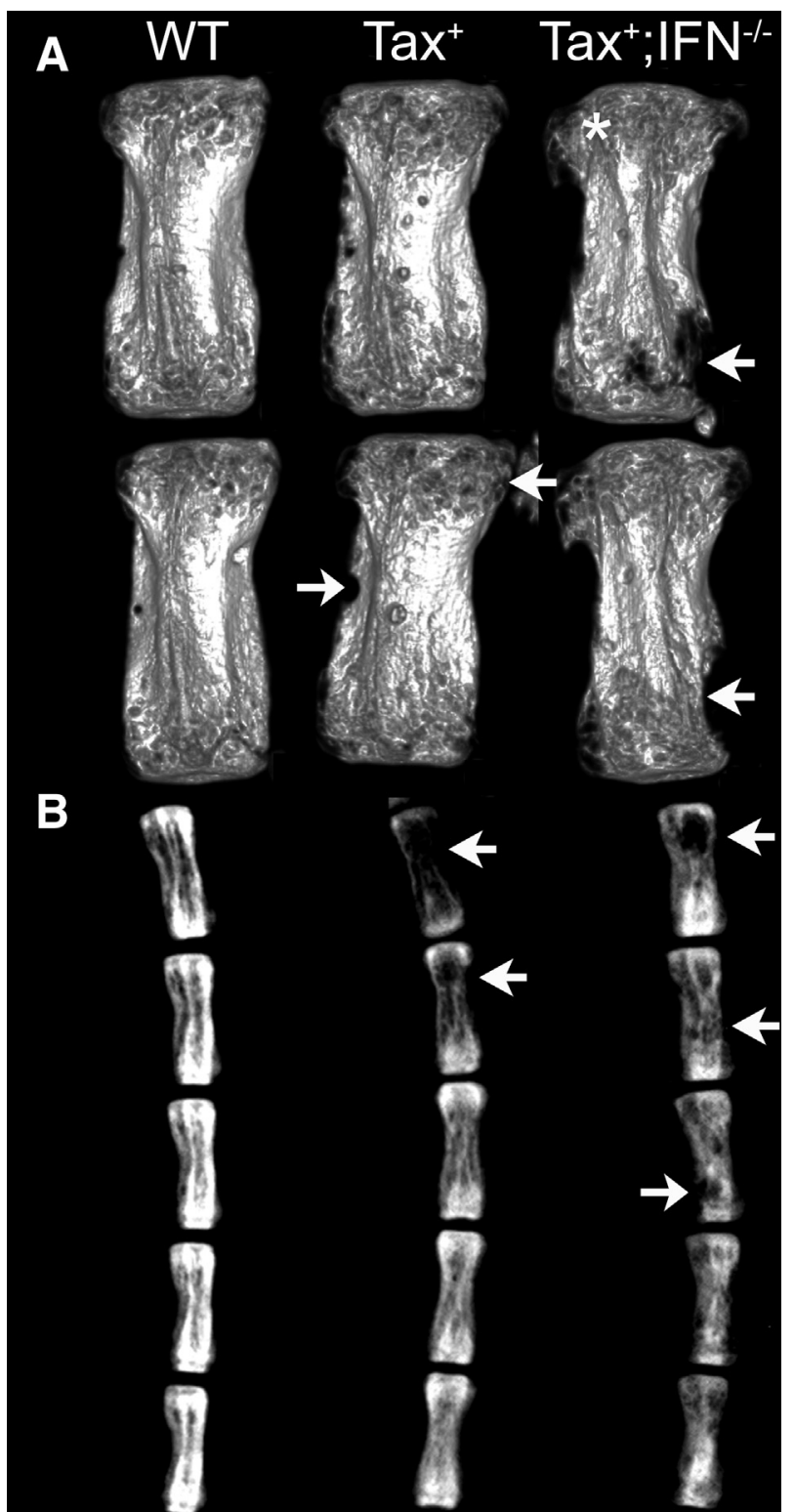

Figure $4 \mathrm{Tax}^{+}$and $\mathrm{Tax}^{+} / \mathrm{IFN}-\gamma^{-/-}$mice have osteolytic lesions in the vertebral metaphysis. A: Micro computed tomography ( $\mu \mathrm{CT}$ ) images from the caudal vertebrae of 12-month-old mice revealed that $\mathrm{Tax}^{+}$mice have increased osteolysis due to histiocytic tumor infiltration (arrows). $\mathrm{Tax}^{+} /$ IFN- $\gamma^{-/-}$mice also have marked multifocal osteolysis secondary to tumor infiltration. The regions of osteolysis have increased radiolucency (arrows). In addition, regions of metaphyseal osteosclerosis were seen by $\mu \mathrm{CT}$ by increased radiopacity compared to wild-type (WT) and $\mathrm{Tax}^{+}$mice (asterisk). B: Digital radiographs reveal multifocal radiolucent regions in $\mathrm{Tax}^{+}$and $\mathrm{Tax}^{+} / \mathrm{IFN}-\gamma^{-1-}$ mice. Bone loss was due to histiocytic tumors originating from tendon sheaths and invaded into bone, most commonly at the cutback zone. Regions of tumor-induced osteolysis have increased radiolucency (arrows).

mice, neither transgenic group had hypercalcemia, with no difference in plasma calcium concentrations between the three groups (WT, $12.5 \pm 0.6 \mathrm{mg} / \mathrm{dL}$; $\mathrm{Tax}^{+}, 11.2 \pm 0.4 \mathrm{mg} / \mathrm{dL}$; and $\left.\mathrm{Tax}^{+} / \mathrm{IFN}-\gamma^{-l-}, 12.1 \pm 1.1 \mathrm{mg} / \mathrm{dL}\right)$. In a study by Gao et al, ${ }^{9}$ a mild increase in serum calcium was reported to have developed in $\mathrm{Tax}^{+}$mice; however, the concentrations were below $12 \mathrm{mg} /$
$\mathrm{dL}$ in both control and $\mathrm{Tax}^{+}$mice. That study also considered only mice with overt osteolytic tumors; in contrast, the entire genetic cohort was included in the present study. In summary, imaging revealed osteolytic lesions in the tail vertebrae at the site of tumor invasion in mice expressing Tax.

\section{$\mathrm{Tax}^{+}$Cell Lines Grew in Vitro and Expressed Macrophage/Monocyte Markers}

Three immortalized cell lines were generated from spontaneous $\mathrm{Tax}^{+} / \mathrm{IFN}-\gamma^{-l-}$ tumors. T94 cells were developed from a tail mass of a 6-month-old female mouse. The 501 cells were generated from a hindlimb osteolytic mass of a 6month-old male mouse. Tom 3 cells were derived from a mixed osteolytic/osteoblastic mass invading the radius and ulna of a 7-month-old male mouse. In culture, T94 cells were moderately sized and spindle shaped, with a single, central, oval nucleus (Figure 5A). The 501 cells were a biphasic population, with small numbers of large, elongated cells with smooth cell borders and smaller, irregularly shaped cells with multiple, thin cytoplasmic projections from the surface (Figure 5B). The Tom 3 cells were moderate in size with multiple, thin projections extending from the cell surface and a single, central, round nucleus. Occasional large and multinuclear Tom 3 cells were present, composing $<20 \%$ of the total cell population (Figure 5C).

Cell lines were labeled with MHCII, CD11b, CD11c, Ly6G, and Ly6C for flow cytometry (Figure 5D). Approximately half of the T94 cells were $\mathrm{Ly} 6 \mathrm{C}^{+}$, with no other surface labeling. Ly6C is nonspecific and cannot be used for definitively identifying the cell line of origin alone. Cells that express Ly6C include monocyte/macrophages, granulocytes, endothelial cells, plasma cells, thymocytes, natural killer cells, and T subsets. Since the T94 cells were adherent, spindle-shaped cells, these characteristics would be consistent with macrophages or endothelial cells. The majority of Tom 3 cells were CD11 ${ }^{+}$and Ly $6 \mathrm{C}^{+}$. These findings, along with the appearances of the cells in culture, are consistent with inflammatory macrophages. The 501 cells were bimodal by flow cytometry, similar to what was seen in culture. The population consisted of CD11b ${ }^{\text {low }}(23 \%$ of cells) and CD11b $\mathrm{b}^{\text {high }}$ (70\% of cells), as well as Ly6C $\mathrm{C}^{\text {low }}$ expression. These findings were consistent with a macrophage/ monocyte population, such as resident monocytes. In summary, while T94 cells were interpreted as macrophage or endothelial in origin, Findings on Tom 3 and 501 cell phenotyping were consistent with these two cell lines being monocyte/macrophage in origin.

\section{$\mathrm{Tax}^{+}$Cell Lines Induced Neutrophilic Infiltration, Splenomegaly, and Hypercalcemia}

All cells engrafted and all mice met ERC by 60 days postinjection due to tumor size or lameness. The T94S cells were the most rapidly growing in all sites, with a mean survival of 19 days postinjection. The mean survival of mice injected with 501 was 43 DPI; and with Tom3 was 54 DPI. 

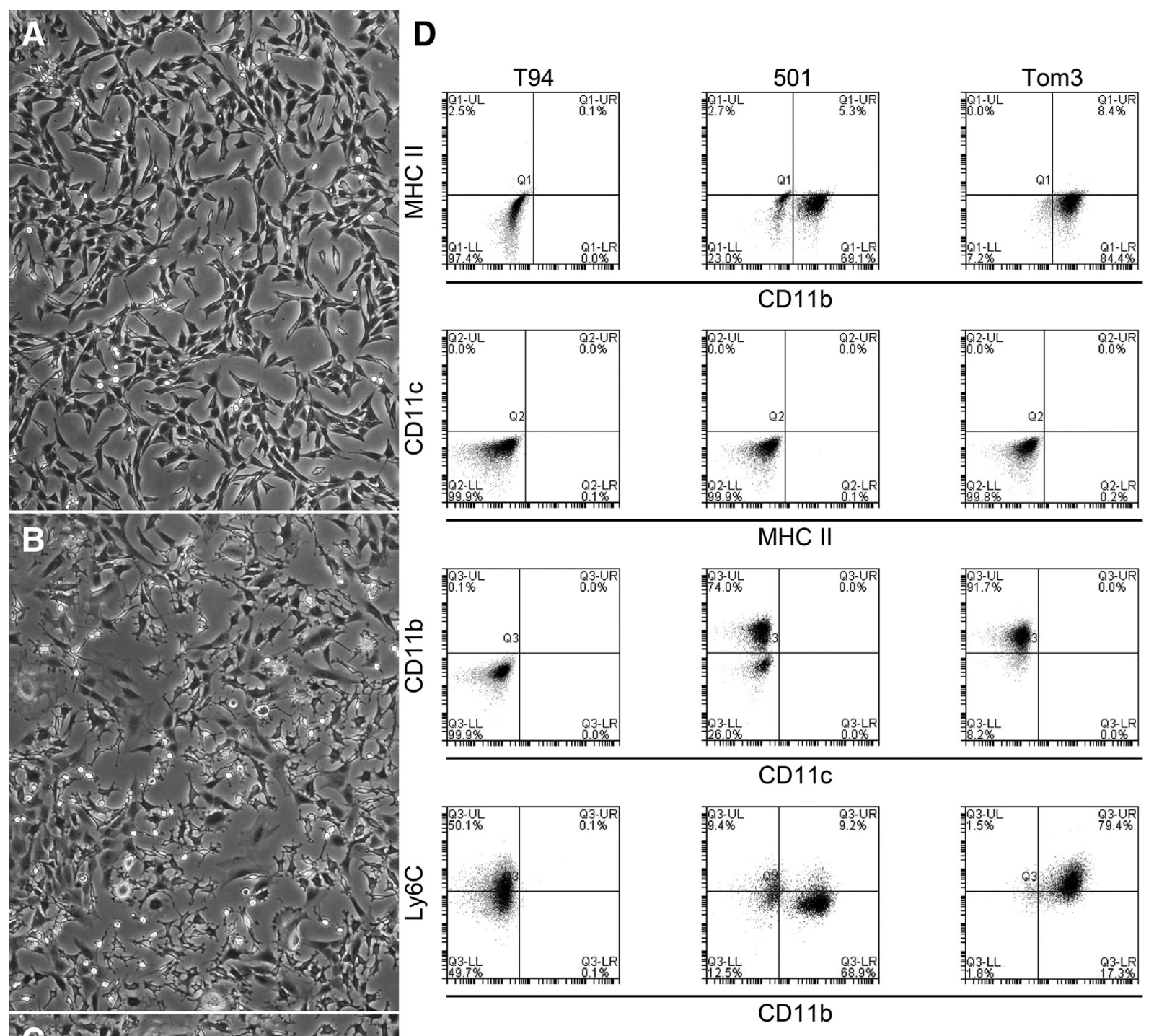

CD11c
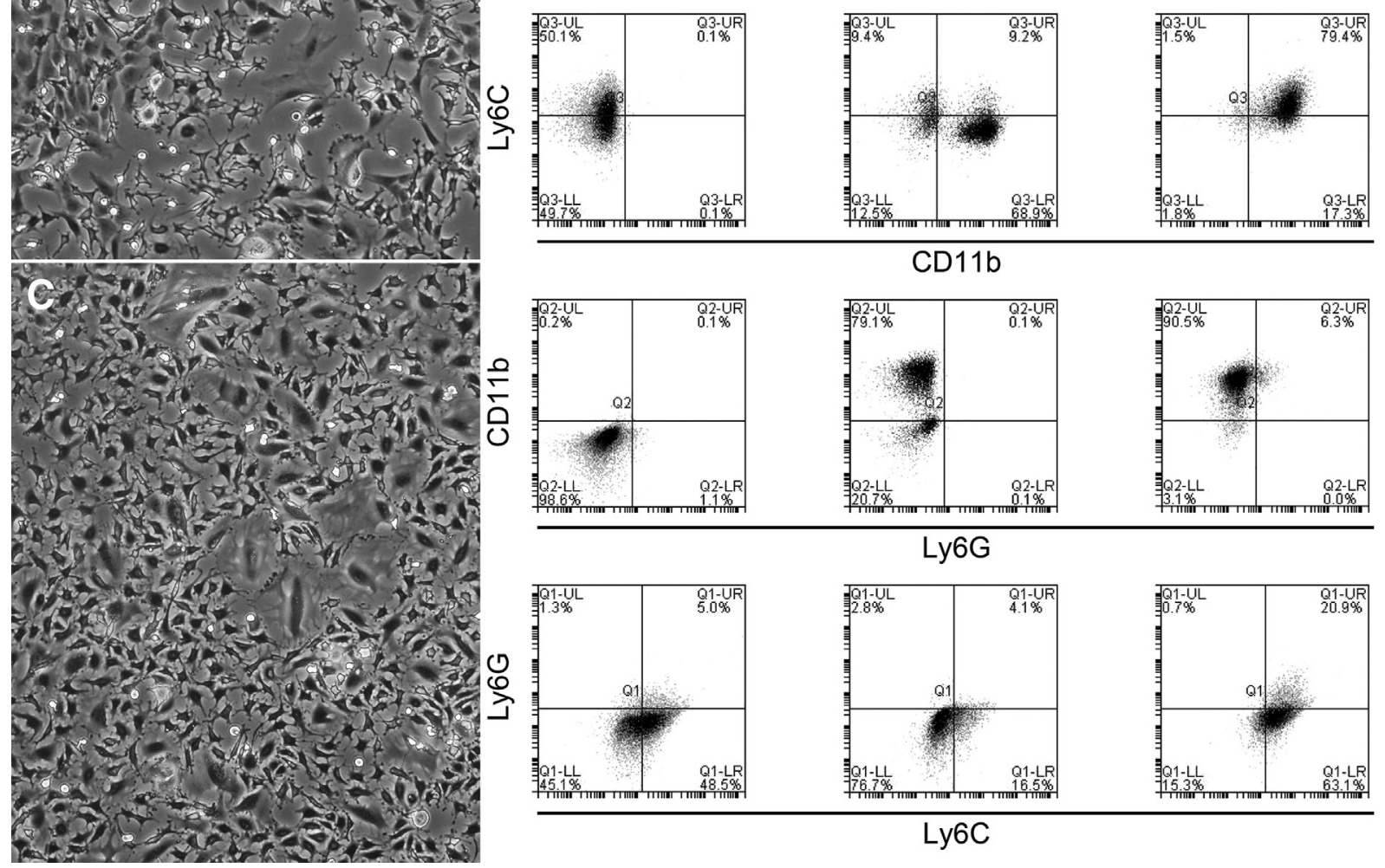

\section{CD11b}

Ly6G

Figure $5 \mathrm{Tax}^{+}$cell lines grown in vitro express macrophage/monocyte markers. A-C: Light microscopy of adherence of all cell lines-T94 (A), 501 (B), and Tom3 (C) - to tissue culture plastic. T94 cells are spindle-shaped, whereas Tom3 are stellate with cytoplasmic projections. The 501 cells are a mixture of both phenotypes, but the stellate morphology predominates. D: Flow cytometric analysis of the original cell preparations demonstrates that T94 cells are positive only for Ly6C. The 501 cells are bimodal, with > half of the cells expressing CD11b and a small proportion expressing low levels of Ly6C. Tom3 expresses CD11b and Ly6C. These data indicate that the 501 and Tom3 cells are macrophage/monocyte in origin. 0bjective magnification: $\times 20$. MHC, major histocompatibility complex. 
Table 2 Summary of Allograft Study Results

\begin{tabular}{|c|c|c|c|c|c|}
\hline No. & $\begin{array}{l}\text { Experimental } \\
\text { procedure }\end{array}$ & $\begin{array}{l}\text { Survival } \\
\text { DPI }\end{array}$ & $\begin{array}{l}\text { Neutrophilic } \\
\text { infiltrate }\end{array}$ & Metastasis & Splenomegaly \\
\hline 1 & T94S SQ & 14 & - & $\mathrm{N}$ & $\mathrm{N}$ \\
\hline 2 & T94S SQ & 14 & - & $\mathrm{N}$ & $\mathrm{N}$ \\
\hline 3 & T94S SQ & 14 & - & $\mathrm{N}$ & $\mathrm{N}$ \\
\hline 4 & T94S IT & 21 & - & $\mathrm{N}$ & $\mathrm{N}$ \\
\hline 5 & T94S IT & 37 & $\begin{array}{l}-,++ \text { in } \\
\quad \text { lung mets }\end{array}$ & $\begin{array}{l}\text { Multifocal } \\
\text { lung }\end{array}$ & $\mathrm{N}$ \\
\hline 6 & T94S IT & 21 & $\begin{array}{l}-,++ \text { in } \\
\text { lung mets }\end{array}$ & $\begin{array}{l}\text { Multifocal } \\
\text { lung }\end{array}$ & $\mathrm{N}$ \\
\hline 7 & T94S BA & 14 & - & $\mathrm{N}$ & $\mathrm{N}$ \\
\hline 8 & T94S BA & 14 & + & $\mathrm{N}$ & $\mathrm{N}$ \\
\hline 9 & $501 \mathrm{SQ}$ & 42 & $-/+++$ & $\mathrm{N}$ & $\mathrm{N}$ \\
\hline 10 & $501 \mathrm{SQ}$ & 37 & + & $\mathrm{N}$ & $\mathrm{N}$ \\
\hline 11 & $501 \mathrm{SQ}$ & 42 & - & $\mathrm{N}$ & $\mathrm{N}$ \\
\hline 12 & 501 IT & 37 & - & $\mathrm{N}$ & $\mathrm{N}$ \\
\hline 13 & 501 IT & 60 & +++ & $\mathrm{N}$ & $\mathrm{N}$ \\
\hline 14 & 501 IT & 48 & + & $\mathrm{N}$ & $\mathrm{N}$ \\
\hline 15 & $501 \mathrm{BA}$ & 42 & $-/+++$ & $\mathrm{N}$ & $\mathrm{N}$ \\
\hline 16 & $501 \mathrm{BA}$ & 37 & $-/+++$ & $\mathrm{N}$ & $\mathrm{N}$ \\
\hline 17 & Tom3 SQ & 50 & ++++ & $\mathrm{N}$ & $Y$ \\
\hline 18 & Tom3 SQ & 50 & ++++ & $\mathrm{N}$ & $Y$ \\
\hline 19 & Tom3 SQ & 59 & ++++ & $\mathrm{N}$ & $Y$ \\
\hline 20 & Tom3 IT & 59 & ++++ & $\mathrm{N}$ & $Y$ \\
\hline 21 & Tom3 IT & 48 & ++++ & $\mathrm{N}$ & $Y$ \\
\hline 22 & Tom3 IT & 48 & ++++ & $\mathrm{N}$ & $Y$ \\
\hline 23 & Tom3 BA & 59 & ++++ & $\mathrm{N}$ & $Y$ \\
\hline 24 & Tom3 BA & 59 & ++++ & $\mathrm{N}$ & $Y$ \\
\hline
\end{tabular}

- , negative; + , minimal; ++ , mild; +++ , moderate; ++++ , marked $\mathrm{DPI}$, days postinjection; mets, metastases; N, no; SQ, subcutaneous injection; IT, intratibial injection; BA, bone adjacent injection; $Y$, yes.

Two of the three mice injected intratibially with T94S cells had grossly visible lung metastasis on euthanasia. An allograft summary is shown in Table 2.

Histologically, the cell lines expressed Tax after in vivo injection when evaluated by IHC analysis, and tumor cells in bone lesions had morphologies similar to cells in vitro. The T94 cells were spindle shaped and monomorphic, with no inflammatory infiltrate (Figure 6A). Tumors that formed at the site of 501 injection consisted of spindle-shaped cells, with minimal to no neutrophilic infiltration (Figure 6B). Several 501 tumors had a biphasic morphology, in which the central population of cells was large and round, with large vesicular nuclei and the peripheral cells were spindle shaped, with elongated nuclei. Interestingly, the central round-cell population was frequently accompanied by a marked neutrophilic infiltration that did not extend into the surrounding spindle-shaped tumor population. Tom3 formed tumors consisting of large, round cells with large, vesicular nuclei and occasional bi- and multinucleated cells with marked neutrophilic infiltrate (Figure 6C). The neutrophilic infiltrate in Tom3 tumors frequently made up $>50 \%$ of the tumor. While spleens associated with s.c. 501 tumors had no increase in myelopoiesis (Figure 6D), the spleens of mice with s.c. Tom3 tumors had large numbers of mature and immature granulocytes and larger myeloid precursors (Figure 6E). Mice bearing Tom3 tumors in any location frequently had splenomegaly due to marked myelopoiesis. Tumors from all cell lines after intratibial injection extended from the marrow space through the cortex. Expansile growth within the adjacent soft tissues was frequently more severe than was the tumor growth within the bone. All cell lines induced osteolysis when injected adjacent to bone or in the tibia, with marked osteolysis 28 days after intratibial injection, as evaluated by histopathology. Lung metastasis was present only with intratibial T94 injections, and unlike their s.c. tumors, lung metastases had moderate neutrophilic infiltration (Figure 6F). There was no difference in plasma calcium levels in mice injected in different locations with the same cell type. Both 501 $(14.0 \pm 0.6 \mathrm{mg} / \mathrm{dL})$ and T94 (13.9 $\pm 0.9 \mathrm{mg} / \mathrm{dL})$-injected mice had HHM, with both also having significantly higher plasma calcium levels than those in Tom3-injected mice (12.8 $\pm 0.5 \mathrm{mg} / \mathrm{dL}$ ) (both, $P<0.01$ ) (Figure 6G). In summary, $\operatorname{Tax}^{+}$cell lines in vivo resembled their in vitro morphology and developed osteolytic lesions. In addition, depending on the route of injection and $\mathrm{Tax}^{+}$cell line, recipient mice developed neutrophilic infiltration, splenomegaly, and metastasis.

\section{Osteolysis Can Be Stimulated in Vitro with CM from $\mathrm{Tax}^{+}$Cells}

For the determination of whether $\mathrm{Tax}^{+} / \mathrm{IFN}-\gamma^{-/-}$tumor cell lines secrete factors that promote osteolysis, tumor CM was incubated with murine calvaria ex vivo, and the osteoclast activity was evaluated. Osteoclast activity was measured by osteoclast-specific TRAP staining and calcium loss into the culture media. Control calvaria had $6.7 \%$ bone lysis and bone loss was increased with T94 CM, but was not statistically significant at $19.4 \% \pm 21.7 \%(P=0.38)$ (Figure 7A). However, the values of percent bone lysis with 501 and Tom $3 \mathrm{CM}(46.6 \% \pm 23.9 \%$ and $62.6 \% \pm 35.7 \%$, respectvely) were significantly higher than those in the control (both, $P<0.01$ ). Increased osteoclast numbers can be appreciated by the increase in calvarial TRAP staining (Figure 7A).

Calcium was measured in the CM before and after calvarial co-culture. There was no difference between cell line $\mathrm{CM}$ and DMEM control (Figure 7B). After co-culture, the calcium in the control media group was $8.0 \pm 0.6 \mathrm{mg} / \mathrm{dL}$, but significantly higher levels were observed in the T94 $(9.5 \pm 1.2 \mathrm{mg} / \mathrm{dL}, P=0.003), 501(10.8 \pm 0.9 \mathrm{mg} / \mathrm{dL}$, $P<0.0001)$, and Tom3 $(11.0 \pm 1.1 \mathrm{mg} / \mathrm{dL}, P<0.0001)$ media. Tom 3 and 501 media calcium levels were significantly higher than those in T94 $(P=0.007$ and 0.003 , respectively) (Figure $7 \mathrm{~B}$ ). In summary, $\mathrm{Tax}^{+}$cell lines increased in vitro osteoclastic bone resorption, as can be observed by increased: number of calvarial osteoclasts and release of calvarial calcium. 

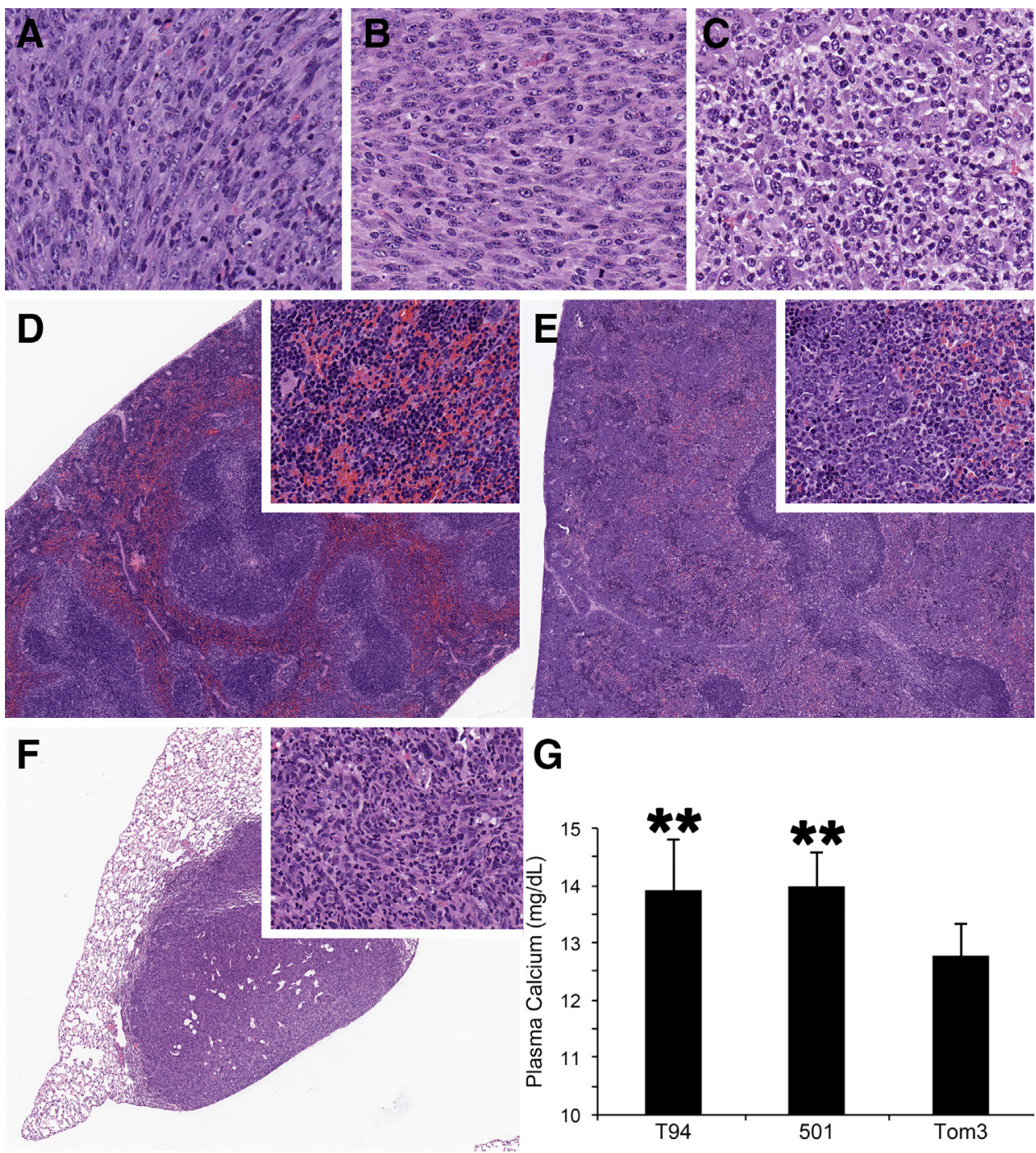

Figure 6 Histopathology and hypercalcemia in allografted mice. All cell lines grown in nude mice. A and B: In the subcutis, T94 (A) and 501 (B) cells are spindle-shaped, with minimal to no neutrophilic infiltrate. C: Tom3 cells are large and round, with vesicular nuclei and abundant neutrophilic infiltrate. D: Spleen with an s.c. 501 tumor has no increase in myelopoiesis. Inset shows red pulp with erythrocytes, lymphocytes, erythroid precursors, and a megakaryocyte. E: Spleen with an s.c. Tom3 tumor has marked red pulp expansion. Inset shows red pulp with large numbers of mature and immature granulocytes, larger myeloid precursors, and a megakaryocyte. F: Lung metastasis is present only in mice with intratibial T94 cells. Unlike the s.c. tumor, the metastases have moderate neutrophilic infiltration (inset). G: Mice injected at any site with T94 and 501 cells have significantly higher plasma calcium levels than do Tom3injected mice. Data are expressed as means \pm SD. ${ }^{*} P<0.01$ versus Tom3. Original magnification: $\times 40(A-C) ; \times 4($ D $-F) ; \times 20($ D $-\mathbf{F}$, insets) .

$\operatorname{Tax}^{+}$Cell Lines Expressed Bone-Modifying Genes with Abundant Expression of Pro-Osteolytic and ProOsteoclastogenic Factors

Real-time RT-PCR was performed to measure the expression of genes relating to osteolysis and the NF- $\kappa$ B pathway (Figure 7C). Human Tax mRNA was abundantly present in all cell lines on RT-PCR, but was not present in normal, nontransgenic mouse tissues (Supplemental Figure S2). Tax is a known regulator of the NF- $\kappa$ B pathway. ${ }^{39}$ Il6 and Pthrp were significantly higher in T94 compared to those in Tom3 and 501 cells (all, $P<0.0001$ ). Interestingly, T94 was the only $\mathrm{Tax}^{+}$cell line that produced grossly visible metastasis in vivo. Opg and Rankl were significantly higher in 501 compared to those in T94 and Tom3 cells (all, $P<0.05$ ), whereas Rank was greater in Tom 3 and 501 compared to that in T94 (both, $P<0.0001$ ). Csf3, Illa, and Illb were significantly higher in Tom 3 compared to 501 and T94 cells, and higher in 501 than in T94 $(P<0.05$ or $<0.0001)$. In summary, T94 expressed the most Il6 and Pthrp, and Tom3 cells expressed the most Csf3, Illa, and Illb.

\section{Discussion}

ATL is a devastating human disease that, in the acute form, is associated with a poor likelihood of survival. With a long latency and low percentage of HTLV-1-infected patients 

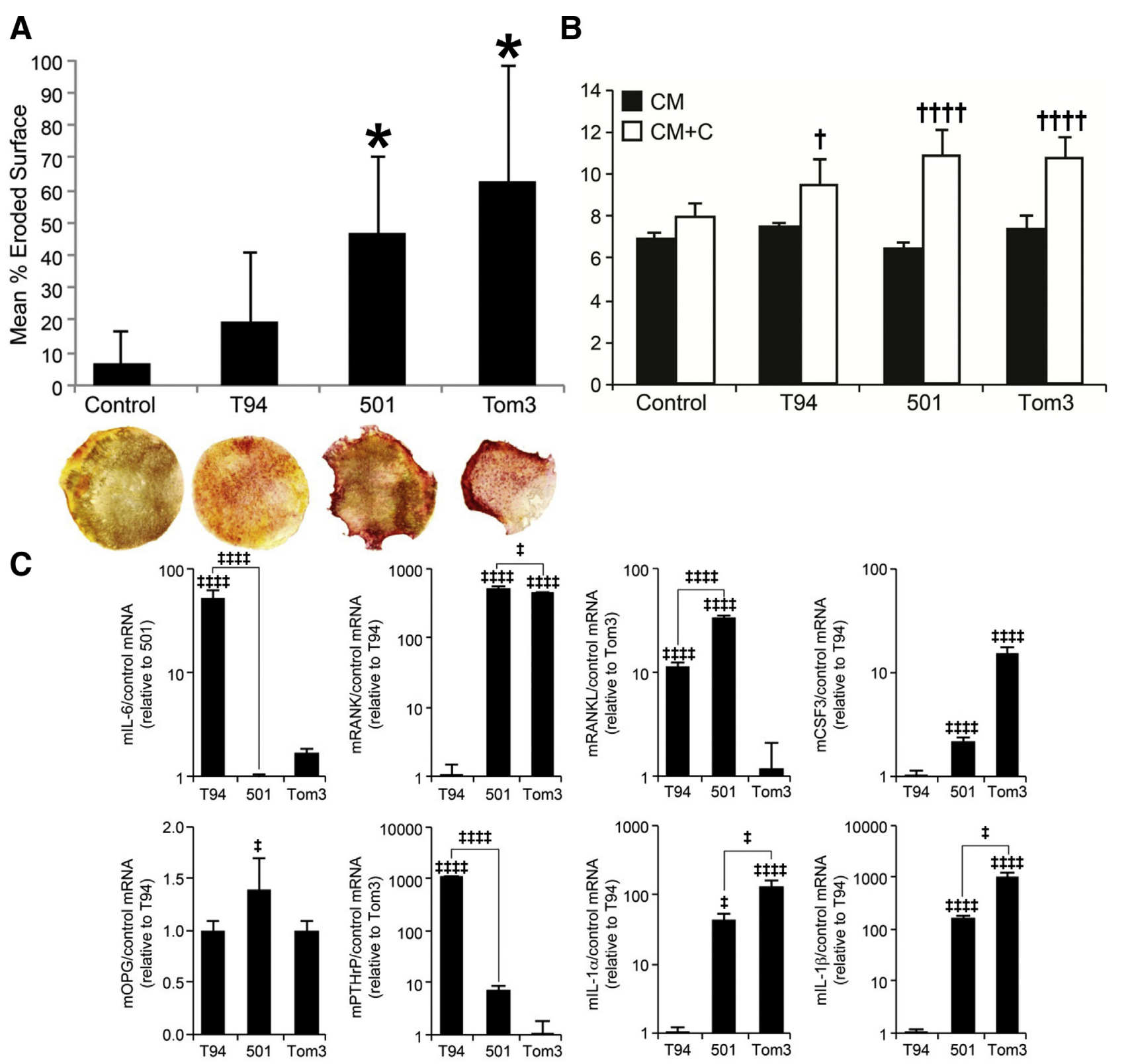

Figure 7 Increased osteolytic bone resorption, calcium release, and gene expression are correlated with increased growth, metastasis, and inflammatory infiltrates. A: In calvarial co-cultures, 501 and Tom 3 conditioned media (CM) had significantly more bone resorption than do control and T94 CM co-cultures, as measured by percent eroded surface (top). Images of TRAP-stained calvaria after co-culture (bottom). The red periphery in the 501 and Tom 3 calvaria is due to increased osteoclast number. B: There was no significant difference between the $\mathrm{CM}$ and control media before co-culture. After co-culture, medium calcium was significantly greater in co-cultures with CM compared to controls, and media calcium levels were greater in Tom3 and 501 cells compared to T94 cells, $P=$ 0.007 and 0.003 , respectively. C: Real-time RT-PCR for the measurement of the expression of genes related to osteolysis and the NF- $\kappa B$ pathway. Data are expressed as means \pm SD. ${ }^{*} P<0.05$ versus control and T94 CM co-cultures; ${ }^{\dagger} P<0.05$ and ${ }^{\dagger \dagger \dagger \dagger} P<0.0001$ versus controls; ${ }^{\ddagger} P<0.05$ and ${ }^{\ddagger \ddagger \ddagger \ddagger} P<0.0001$ versus the lowest-expressing cell line, or as indicated. $\mathrm{C}+\mathrm{CM}=$ conditioned media + co-culture; $\mathrm{mCSF}$, murine colony-stimulating factor; $\mathrm{mIL}$, murine IL; mOPG, murine tumor necrosis factor receptor superfamily member 11B (osteoprotegerin); mPTHrP, murine parathyroid hormone-related protein; mRANK, receptor activator of NF-KB; mRANKL, murine receptor activator of NF- $\mathrm{KB}$ ligand.

developing ATL, there is not a thorough understanding of the pathogenesis from viral integration to the development of ATL. Retroviral oncogenesis is not unique to HTLV-1, which induces tumorigenesis through the expression of the oncogene Tax; that is, both necessary and sufficient for oncogenesis. ${ }^{17,40,41}$ Examination of ATL oncogenesis and progression using animal models is vital for further understanding human disease, and developing effective prevention of and therapeutics for HTLV-1 and ATL. The development of transgenic HTLV-1 $\mathrm{Tax}^{+}$mice that develop consistent, osteolytic tumors was a major first step in better understanding the role of HTLV-1 Tax in the formation and progression of osteolytic metastasis and HHM in ATL.

In this study, tumor progression was initially evaluated in mice expressing HTLV-1 Tax driven by the human granzyme B promoter $\left(\mathrm{Tax}^{+}\right)$. Tumor evaluation was performed 
using gross examination, histologic examination, IHC analysis, flow cytometry, and advanced imaging. From these examinations, it was found that HS originated around tendon and nerve sheaths and the perichondrium, with bone invasion and lysis. In addition, $\mathrm{Tax}^{+}$mice had increased bone marrow and splenic hematopoiesis, resulting in splenomegaly and leukocytosis. It was previously reported that the human granzyme B promoter specifically targeted Tax expression to mature CD8 T cells and cytotoxic CD4 subsets, resulting in large-granular-lymphocyte leukemia/ lymphomas. ${ }^{27}$ Since then, it has been shown that the same $\mathrm{Tax}^{+}$mice develop HS originating in the ears and limbs, and from tail tendon sheaths, which is consistent with the findings from the present study. ${ }^{30-32}$ HSs and histiocyteassociated lymphomas in mice are difficult to distinguish histologically. ${ }^{42} \mathrm{HS}$ cells are predominantly round or spindle shaped. Round cells are more mature and have higher F4/80 expression, which increases with monocyte/macrophage maturation. ${ }^{43}$ Prominent nuclear atypia, vesiculated chromatin, and eosinophilic cytoplasm are key features, resembling the human disease. ${ }^{42,44}$ Spontaneous HSs in WT mice typically develop with the liver, spleen, mesentery, uterus, or lung as the primary site, but not in the tail, ears, or limbs. ${ }^{42,45,46}$ In the present study, the peritendinous/perineural tumors were composed of histiocytic cells that were large and round to spindle shaped, with oval to round nuclei and coarsely stippled chromatin. The majority of F4/80 cells had decreased cytoplasmic staining as they transitioned from differentiated round cells to less-differentiated, spindle-shaped cells, a key feature of HSs ${ }^{42}$ It is more common to find HSs in soft tissues invading bone compared to lymphomas. It would also be unexpected to see distalextremity lymphomas without lymph node, spleen, or thymic involvement. Granzyme B was initially described in cytotoxic $\mathrm{T}$ lymphocytes and natural killer cells, but has since been shown to be expressed in DCs, mast cells, basophils, and macrophages, and its expression has been associated with inflammation. ${ }^{47-50}$ In the present study, granzyme B expression was increased in $\mathrm{Mac}-1^{+}$histiocytic tumor cells, but not in B and T lymphocytes, after stimulation with phorbol-myristate-acetate and ionomycin, drugs that when used in combination increase inflammatory cytokine release. The increased granzyme B expression correlates with reports of granzyme B expression by macrophages in the presence of inflammation, whereby it may play a role in macrophage function associated with disease progression. ${ }^{47}$

Several Tax-expressing transgenic mice have been developed, which develop tumors including large-granular-lymphocyte leukemia/lymphomas and inflammatory diseases such as arthritis. However, until recently, there have been no models that completely recapitulate T-cell leukemia and lymphoma as in ATL. ${ }^{20}$ The use of the distal tyrosineprotein kinase Lck promoter to drive Tax expression in mature thymocytes and peripheral $\mathrm{T}$ lymphocytes has been reported to result in mature T-cell leukemia and lymphomas consisting of $\mathrm{CD} 4^{+}, \mathrm{CD}^{+}$, or $\mathrm{CD} 4^{+} \mathrm{CD} 8^{+}$T cells. ${ }^{51}$ While these mice more closely resembled ATL than have previous models, with a prevalence of $22 \%$ to $28 \%$, a small number of these mice reportedly developed HSs in the vertebral bone marrow. ${ }^{44,51}$ HSs in these mice invaded into the spinal cord, resulting in HTLV-1-associated myelopathy/tropical spastic paraparesis (HAM/TSP)-like symptoms. Cells from these HSs were positive for Mac-2, CD68, and F4/80, all histiocyte/macrophage markers, but were negative for CD3, CD19, CD11b, and Ly6G. ${ }^{44}$ Similarly, the histiocytic tumor cells in the present study were consistently double positive for F4/80 and HTLV-1 Tax and negative for T- (CD3) and B- (CD20) cell markers. However, while the $\mathrm{Tax}^{+}$tumors and two cell lines in the present study were also $\mathrm{Ly}_{6 \mathrm{G}}{ }^{-}$, they were in fact $\mathrm{CD}_{11} \mathrm{~b}^{+}\left(\mathrm{Mac}_{-1}^{+}\right)$, indicating that they were macrophage/ monocyte in origin.

Proinflammatory cytokine exposure is believed to be protumorigenic. ${ }^{20}$ Not only is Tax immunogenic, but also inflammation has been reported to increase tumor formation in the $\mathrm{Tax}^{+}$mice utilized for the present studies. ${ }^{33}$ The tumorigenesis of Tax is supported by the development of inflammatory diseases in Tax transgenic mice. Previous models expressing HTLV-1 Tax driven by the human CD4 promoter, as well as the HTLV-1 long terminal repeat, frequently developed inflammation around the joints of the distal extremities. ${ }^{26,52}$ Alterations in inflammatory cytokine expression by HTLV-1 Tax has been documented and has most commonly been associated with activation of the NF$\kappa \mathrm{B}$ pathway. ${ }^{39}$ The association between Tax expression and inflammation, in addition to the large number of mature neutrophils in tumors, suggests that a possible mechanism for HSs development in transgenic mice expressing HTLV1 Tax on the granzyme B promoter involves: initial inflammation around tendons or nerves, followed by activation of granzyme B in macrophages/monocytes located near tendons/nerves and subsequent HTLV-1 Tax expression. The fact that HSs developed peripherally on the ears, nose, tails, and feet, which are common sites of trauma and inflammation due to negligible or lack of a protective hair coat in these regions, supports an inflammatory component to the initiation and progression of the HSs. HSs have been reported to arise from the ears and hindlimbs of the $\mathrm{Tax}^{+}$ mice used in the present study, consisting primarily of histiocytic tumor cells with dispersed round cells, sparse spindle cells, and neutrophilic infiltrates. ${ }^{30}$ In addition, it was reported prior to this study and more recently that the immune response accompanying HSs arising in the tail and tendon sheaths may include large-granular-lymphocyte and neutrophil infiltration. ${ }^{31,32}$ The findings from those studies support the diagnosis of peripheral HSs in $\mathrm{Tax}^{+}$mice.

Tax-expressing $\mathrm{T}$ cells in the distal Lck promoter model are believed to stimulate the proliferation and transformation of bone marrow histiocytes, leading to HSs. ${ }^{44}$ The fact that the infiltrating HS cells in these mice did not express Tax and the expression of Tax was lower than that in both healthy and leukemic mice support the concept of Tax-expressing T cells 
inducing histiocyte transformation. ${ }^{44}$ However, several reports have described a relationship between HTLV-1 and histiocytic disorders and histiocytomas. ${ }^{53-55}$ Tax-driven DC replication and maturation (like macrophages, cells of the myeloid lineage) are implicated in the pathogenesis of HAM/ TSP. ${ }^{56}$ HTLV-1-infected rats have been reported to develop HAM/TSP with spinal cord degeneration and peripheral nerve lesions with extensive macrophage infiltration. ${ }^{57}$ One study reported that, after HTLV-1 infection in mice, tumors did not consist of ATL-like cells but developed splenomegaly containing histiocytic malignancies or sarcomas in other organs with no splenic changes. ${ }^{58}$ HTLV-1-infected cells may also produce factors that stimulate cell growth and generate a suitable microenvironment for spontaneous tumor formation. T-cell activation has been associated with tumor development in the $\mathrm{Tax}^{+}$mice used in the present study. ${ }^{59}$ Despite these findings, at the time of diagnosis, the HSs in the $\mathrm{Tax}^{+}$mice in the present study were $\mathrm{F} 4 / 80^{+}, \mathrm{Tax}^{+}, \mathrm{CD} 11 \mathrm{~b}^{+}\left(\mathrm{Mac}-1^{+}\right)$, and negative for T-lymphocyte markers.

An ATL model recapitulating all steps from viral infection through oncogenesis with $100 \%$ penetrance is not currently available. In order to study various disease aspects, multiple, distinct animal models must be used. Human cells infected with HTLV-1 have been used for in vitro experiments exploring gene expression related to transformation and osteolysis. ${ }^{60,61}$ Most HTLV-1-infected cells used in vitro do not consistently develop xenografts in vivo. ATL xenograft studies have mainly used nonobese diabetic/severe combined immunodeficiency (NOD/SCID) mice. It has recently been shown by the authors that HT-1RV cells, which express high levels of Tax, failed to engraft after intratibial injection in NOD/SCID, but had improved engraftment in more-immunodeficient NOD/SCID $\gamma$ mouse (NSG; The Jackson Laboratory, Bar Harbor, ME) mice. ${ }^{62}$ Conversely, many cell lines grown as xenografts have low survival in culture, making them useful for in vivo therapeutic, but not in vitro mechanistic, studies. ${ }^{35}$ Although they cannot serve as a model for HTLV-1 transformation and oncogenesis, non-virally induced lymphoma cell lines, such as human Jurkat cells, that mimic ATL in vivo and grow well in vitro, have been used for studying gene function in vitro and as in vivo xenografts in mice. ${ }^{63}$ An additional goal in this study was to derive immortalized, tumorigenic cell lines induced by HTLV-1 Tax for in vitro and in vivo use, of which all formed tumors in immunodeficient mice. Based on high CD11b (Mac-1) expression, 501 and Tom 3 cells were macrophage/monocyte in origin. The lack of MHCII in monocyte/macrophage origin cells was unexpected. The primary antibody is haplotype specific for C57BL/6 monocytes. Given that these mice are C57BL/ 6.SJL, the lack of haplotype specificity of the antibody was likely the cause of lack of MHCII staining. Inflammation-specifically: i) neutrophilia, ii) neutrophilic infiltration of tumors, and iii) splenomegaly due to increased colonystimulating factors (CSFs) 3 and 2-has been seen in xenografts and transgenic mice due to HTLV-1 Tax. ${ }^{64-66}$
Tom3 had the highest $C s f 3$, followed by 501 cells. This finding is consistent with the marked neutrophilic infiltrate seen in Tom3, and to a lesser extent 501, allografts. The high level of $C s f 3$ expression also supports the splenomegaly observed in Tom3-bearing mice, which resulted from marked granulopoiesis-myelopoiesis. The use of the cell lines generated in the present study is advantageous based on successful engraftment at all injection sites in nude mice. Further studies are needed for investigating metastasis and disease progression of these cell lines after intravascular and intraosseous delivery, as was recently done with other ATL cell lines that do or do not express Tax..$^{62,67}$

In this article, in vivo osteolysis in the $\mathrm{Tax}^{+}$and $\mathrm{Tax}^{+} /$ IFN $-\gamma^{-1-}$ mice was documented by histologic staining with hematoxylin and eosin, digital radiography, and micro computed tomography. In addition, the three cell lines (501, T94, and Tom3) derived from tumors elicited osteolysis in vitro in calvarial co-culture (501 and Tom 3 were the most osteolytic) and in vivo after intratibial and bone-adjacent injection. Three co-authors who are board-certified veterinary pathologists (L.G.L., T.J.R., and J.M.W.) confirmed histologically that the tumor-induced bone loss and resultant osteolytic bone phenotype was due to increased osteoclast activity in vivo. The co-authors have reported that the $\mathrm{Tax}^{+}$ and $\mathrm{Tax}^{+} / \mathrm{IFN}-\gamma^{-1-}$ mice used in the present study had increased numbers of osteoclasts adjacent to the tail vertebral tumors in $\mathrm{Tax}^{+}$mice, as demonstrated by osteoclastspecific TRAP staining. ${ }^{9,38}$ The co-authors have also reported that osteoclast number and osteoclast perimeter (both per bone surface) were greater in $\mathrm{Tax}^{+} / \mathrm{IFN}-\gamma^{-l-}$ mice compared to those in $\mathrm{Tax}^{+}$mice. ${ }^{29}$ In addition, 12month-old tumor-bearing $\mathrm{Tax}^{+}$mice had decreased in vivo bone formation as evidenced by calcein-double labeling (Supplemental Figure S1A), and reduced osteoblast progenitors in the mineralizing condition, but not fibroblast progenitors in the basal condition (Supplemental Figure S1B), when compared to WT mice. These findings indicate that peritumoral bone lesions resulted from both an increase in osteoclast and a decrease in osteoblast activity, which is a typical finding in osteolytic malignancies.

HHM is common in patients with ATL. ${ }^{68}$ Parathyroid hormone-related protein (PTHrP) plays a central role by indirectly increasing osteoclastic bone resorption and inhibiting renal calcium excretion. ${ }^{69}$ The initiation of NF- $\kappa \mathrm{B}$ signaling by HTLV-1 Tax is crucial for cellular transformation and is frequently attributed to increasing circulating PTHrP and HHM in ATL. ${ }^{39}$ Pthrp in ATL or HTLV-1-infected cells have been shown to be regulated by NF- $\kappa B .{ }^{70}$ In the novel cell lines, Pthrp was not correlated with differences in Tax between the cells, suggesting that although Tax initiated NF- $\kappa \mathrm{B}$, continued expression was Tax independent. However, Pthrp was correlated with HHM. Pthrp expression by T94 and 501 was significantly greater than that in Tom3 cells. Mice injected with T94 and 501 cells also had HHM and significantly higher plasma calcium than that in Tom3 mice. However, i) all three cell 
lines induced in vivo osteolysis after intratibial injection, ii) T94 cells metastasized to the lungs after intratibial injection, and iii) T94 and 501 cells induced HHM independent of the injection site. Survival and the proliferation of neoplastic cells in vivo was directly correlated with Pthrp and Il6. T94 cells expressed the highest levels of both. The marked Il6 increase in T94 cells was correlated with faster tumor engraftment and growth of T94 allografts. IL-6 is a potent growth stimulator in multiple tumors, including prostate and breast cancers and multiple myeloma. ${ }^{71-73}$ Mice injected with T94 cells had the shortest survival time, regardless of injection site, and mice injected intratibially with T94 cells had multifocal lung metastases, likely from increased Pthrp. A relationship between Pthrp and cancer proliferation and metastasis has been reported. ${ }^{74-76}$ Pthrp in T94 and 501 cells has not been correlated with osteolysis and calcium levels in the calvarial co-cultures. ${ }^{77}$ PTHrP cannot directly induce osteoclast differentiation, requiring an osteoblast or immune cell intermediate. In contrast, IL-1 directly induces osteoclast maturation and function. ${ }^{78}$ The 501 and Tom3 cells had Ill $a$ and $I l l b$ levels significantly greater than those in T94 cells, and osteolysis and media calcium levels higher than that in both T94 and control co-cultures. Protein levels associated with these gene expression differences were not measured. The expression of intracellular or secreted proteins in these cell lines should be performed in the future to determine the full spectrum of secreted immune and bonemodulatory factors.

The mean plasma calcium levels were higher in allografted mice (501-injected mice, $14.0 \mathrm{mg} / \mathrm{dL}$; T94, $13.9 \mathrm{mg} /$ $\mathrm{dL}$; and Tom3, $12.8 \mathrm{mg} / \mathrm{dL}$ ) when compared to those in WT mice $(12.5 \mathrm{mg} / \mathrm{dL}), \mathrm{Tax}^{+}$mice $(11.2 \mathrm{mg} / \mathrm{dL})$, and $\mathrm{Tax}^{+} /$ IFN- $\gamma^{-1-}$ mice $(12.1 \mathrm{mg} / \mathrm{dL})$. The reason for increased plasma calcium in allografted mice was likely multifactorial. First, cell lines were injected at doses of $2 \times 10^{5}$ cells for intratibial, $5 \times 10^{5}$ cells for bone-adjacent, and $1 \times 10^{6}$ cells for s.c. tumors. All tumors engrafted and only two intratibial mice in the T94S group developed metastasis. Therefore, tumors in cell-line-injected mice grew much larger with time than did spontaneous tumors in the $\mathrm{Tax}^{+}$and $\mathrm{Tax}^{+}$/ IFN $-\gamma^{-1-}$ mice. Second, there were differences in the ages of the mice. Cell line-injected mice were 6 weeks of age, which is the rapid growth phase and pubertal period in mice, and lived between 14 to 60 days after injection ( 2 to 4 months of age) (Table 2). In contrast, transgenic mice and age-matched WT controls were 12 months of age when calcium levels were measured. It is known that, in humans, calcium levels are higher during the rapid pubertal growth phase and decline in people $>50$ years of age. Similarly, it has been shown that in mice, serum calcium levels begin to decrease after 3 months of age. ${ }^{79}$ The ages of the mice in the present study reflect these different age periods and also contributed to allografted mice having higher blood calcium levels. Lastly, while using the same assay for measuring calcium levels, the transgenic mice and WT controls were measured at the same time on the same plate (assay), and the allografted mice were measured together on the same plate (assay), but at a different time than were the transgenic mice. Between-plate (assay) differences may have also contributed to slight differences between allografted and transgenic mice despite the use of internal standards and controls within each plate. HHM was not found in the $\mathrm{Tax}^{+}$ and $\mathrm{Tax}^{+} / \mathrm{IFN}-\gamma^{-l-}$ mice, and the lack of HHM may be related to the fact we did not correct for circulating albumin and measured calcium levels in the entire genetic cohort rather than just in mice with overt osteolytic lesions, as was done previously. ${ }^{9,29}$

These mice are a useful model of HTLV-1 Tax-induced malignancy and can be used for studying the mechanisms of cancer-bone interactions in bone-invasive and osteolytic tumors. The three immortal and tumorigenic $\mathrm{Tax}^{+}$cell lines in the present study support what is known regarding Pthrp, $I l 1, I l 6$, and Csfg as they relate to the development of boneinvasive tumors and HHM, tumor proliferation, and neutrophilic inflammation and myelopoiesis in ATL. The consistent formation of peripheral bone-invasive tumors in $\mathrm{Tax}^{+}$mice and the transplantable cell lines will facilitate in vivo and in vitro research on the mechanisms of HTLV-1 oncogenesis, HHM, and tumor-induced inflammation. Such research will foster the creation of therapeutics targeting HTLV-1 Tax, a necessary protein in ATL development, as was shown with bisphosphonates being effective in reducing not only osteoclast activity and resultant osteolysis, but also tumor cell growth in $\mathrm{Tax}^{+}$mice. ${ }^{9,80}$

The relationship between HTLV-1 infection and histiocytic disorders should be the focus of future studies. In particular, examining whether the oncogenic transformation and growth of histiocytes toward the formation of HS are a result of factors secreted from other Tax-expressing cells and/or intracellular Tax expression will offer important insights in osteolytic tumor formation.

\section{Acknowledgments}

We thank Alan Flechtner, Anne Saulsbery, and Florinda Jaynes for tissue processing and preparation of slides; Shelly Haramia for slide scanning; Tim Vojt for assistance with figures; Michelle Hurchla for assistance with specimen acquisition; and Michelle Williams for micro computed tomography technical support.

\section{Supplemental Data}

Supplemental material for this article can be found at http://doi.org/10.1016/j.ajpath.2020.10.014.

\section{References}

1. Blayney DW, Blattner WA, Robert-Guroff M, Jaffe ES, Fisher RI, Bunn PA Jr, Patton MG, Rarick HR, Gallo RC: The human T-cell 
leukemia-lymphoma virus in the southeastern United States. JAMA 1983, 250:1048-1052

2. Haratake J, Horie A, Oda S, Chiba S, Kobori K, Sato H: A clinicopathological review of 12 autopsied cases of adult T-cell leukemia. Acta Pathol Jpn 1986, 36:349-362

3. Ratner L: Adult T cell leukemia lymphoma. Front Biosci 2004, 9: $2852-2859$

4. Ratner L: Human T cell lymphotropic virus-associated leukemia/lymphoma. Curr Opin Oncol 2005, 17:469-473

5. Uchiyama T: Human T cell leukemia virus type I (HTLV-I) and human diseases. Annu Rev Immunol 1997, 15:15-37

6. Kohart NA, Elshafae SM, Breitbach JT, Rosol TJ: Animal models of cancer-associated hypercalcemia. Vet Sci 2017, 4:21

7. Roodman GD: Mechanisms of bone lesions in multiple myeloma and lymphoma. Cancer 1997, 80:1557-1563

8. Simmons JK, Hildreth BE 3rd, Supsavhad W, Elshafae SM, Hassan BB, Dirksen WP, Toribio RE, Rosol TJ: Animal models of bone metastasis. Vet Pathol 2015, 52:827-841

9. Gao L, Deng H, Zhao H, Hirbe A, Harding J, Ratner L, Weilbaecher K: HTLV-1 Tax transgenic mice develop spontaneous osteolytic bone metastases prevented by osteoclast inhibition. Blood 2005, 106:4294-4302

10. Jeang KT: Functional activities of the human T-cell leukemia virus type I Tax oncoprotein: cellular signaling through NF-kappa B. Cytokine Growth Factor Rev 2001, 12:207-217

11. Jeang KT, Widen SG, Semmes OJT, Wilson SH: HTLV-I transactivator protein, Tax, is a trans-repressor of the human betapolymerase gene. Science 1990, 247:1082-1084

12. Neuveut C, Jeang KT: HTLV-I Tax and cell cycle progression. Prog Cell Cycle Res 2000, 4:157-162

13. Van Orden K, Nyborg JK: Insight into the tumor suppressor function of CBP through the viral oncoprotein Tax. Gene Expr 2000, 9:29-36

14. Grassmann R, Aboud M, Jeang KT: Molecular mechanisms of cellular transformation by HTLV-1 Tax. Oncogene 2005, 24:5976-5985

15. Li XH, Gaynor RB: Mechanisms of NF-kappaB activation by the HTLV type 1 Tax protein. AIDS Res Hum Retroviruses 2000, 16:1583-1590

16. Pozzatti R, Vogel J, Jay G: The human T-lymphotropic virus type I TAX gene can cooperate with the Ras oncogene to induce neoplastic transformation of cells. Mol Cell Biol 1990, 10:413-417

17. Tanaka A, Takahashi C, Yamaoka S, Nosaka T, Maki M, Hatanaka M: Oncogenic transformation by the TAX gene of human T-cell leukemia virus type I in vitro. Proc Natl Acad Sci U S A 1990, $87: 1071-1075$

18. Grossman WJ, Ratner L: Transgenic mouse models for HTLV-I infection. J Acquir Immune Defic Syndr Hum Retrovirol 1996, 13(Suppl 1):S162-S169

19. Lairmore MD, Silverman L, Ratner L: Animal models for human Tlymphotropic virus type 1 (HTLV-1) infection and transformation. Oncogene 2005, 24:6005-6015

20. Ohsugi T: A transgenic mouse model of human T cell leukemia virus type 1-associated diseases. Front Microbiol 2013, 4:49

21. Nerenberg MI: An HTLV-I transgenic mouse model: role of the Tax gene in pathogenesis in multiple organ systems. Curr Top Microbiol Immunol 1990, 160:121-128

22. Bieberich CJ, King CM, Tinkle BT, Jay G: A transgenic model of transactivation by the Tax protein of HTLV-I. Virology 1993, 196: 309-318

23. Kotani M, Tagawa Y, Iwakura Y: Involvement of autoimmunity against type II collagen in the development of arthritis in mice transgenic for the human T cell leukemia virus type I TAX gene. Eur J Immunol 1999, 29:54-64

24. Ruddle NH, Li CB, Horne WC, Santiago P, Troiano N, Jay G, Horowitz M, Baron R: Mice transgenic for HTLV-I LTR-Tax exhibit Tax expression in bone, skeletal alterations, and high bone turnover. Virology 1993, 197:196-204

25. Saggioro D, Rosato A, Esposito G, Rosenberg MP, Harrison J, Felber BK, Pavlakis GN, Chieco-Bianchi L: Inflammatory polyarthropathy and bone remodeling in HTLV-I Tax-transgenic mice. J Acquir Immune Defic Syndr Hum Retrovirol 1997, 14: 272-280

26. Habu K, Nakayama-Yamada J, Asano M, Saijo S, Itagaki K, Horai R, Yamamoto H, Sekiguchi T, Nosaka T, Hatanaka M, Iwakura Y: The human $\mathrm{T}$ cell leukemia virus type I-TAX gene is responsible for the development of both inflammatory polyarthropathy resembling rheumatoid arthritis and noninflammatory ankylotic arthropathy in transgenic mice. J Immunol 1999, 162:2956-2963

27. Grossman WJ, Kimata JT, Wong FH, Zutter M, Ley TJ, Ratner L: Development of leukemia in mice transgenic for the TAX gene of human T-cell leukemia virus type I. Proc Natl Acad Sci U S A 1995, 92:1057-1061

28. Mitra-Kaushik S, Harding J, Hess J, Schreiber R, Ratner L: Enhanced tumorigenesis in HTLV-1 Tax-transgenic mice deficient in interferongamma. Blood 2004, 104:3305-3311

29. Xu Z, Hurchla MA, Deng H, Uluckan O, Bu F, Berdy A, Eagleton MC, Heller EA, Floyd DH, Dirksen WP, Shu S, Tanaka Y, Fernandez SA, Rosol TJ, Weilbaecher KN: Interferon-gamma targets cancer cells and osteoclasts to prevent tumor-associated bone loss and bone metastases. J Biol Chem 2009, 284:4658-4666

30. Zane L, Yasunaga J, Mitagami Y, Yedavalli V, Tang SW, Chen CY, Ratner L, Lu X, Jeang KT: Wip1 and p53 contribute to HTLV-1 Taxinduced tumorigenesis. Retrovirology 2012, 9:114

31. Ward JM, Schofield PN, Sundberg JP: Reproducibility of histopathological findings in experimental pathology of the mouse: a sorry tail. Lab Anim (NY) 2017, 46:146-151

32. Montali RJ, Fredrickson T, Chi YH, Jeang KT, Ward JM: HTLV-1 Tax transgenic mice develop an array of mesenchymal tumors with unique tissue origins. Vet Pathol 2006, 43:838

33. Rauch D, Gross S, Harding J, Niewiesk S, Lairmore M, PiwnicaWorms D, Ratner L: Imaging spontaneous tumorigenesis: inflammation precedes development of peripheral NK tumors. Blood 2009, 113:1493-1500

34. Grone A, Weckmann MT, Blomme EA, Capen CC, Rosol TJ: Dependence of humoral hypercalcemia of malignancy on parathyroid hormone-related protein expression in the canine anal sac apocrine gland adenocarcinoma (CAC-8) nude mouse model. Vet Pathol 1998, 35:344-351

35. Shu ST, Nadella MV, Dirksen WP, Fernandez SA, Thudi NK, Werbeck JL, Lairmore MD, Rosol TJ: A novel bioluminescent mouse model and effective therapy for adult T-cell leukemia/lymphoma. Cancer Res 2007, 67:11859-11866

36. Vandesompele J, De Preter K, Pattyn F, Poppe B, Van Roy N, De Paepe A, Speleman F: Accurate normalization of real-time quantitative RT-PCR data by geometric averaging of multiple internal control genes. Genome Biol 2002, 3. RESEARCH0034

37. Gao Y, Grassi F, Ryan MR, Terauchi M, Page K, Yang X, Weitzmann MN, Pacifici R: IFN-gamma stimulates osteoclast formation and bone loss in vivo via antigen-driven $\mathrm{T}$ cell activation. J Clin Invest 2007, 117:122-132

38. Wadas TJ, Deng H, Sprague JE, Zheleznyak A, Weilbaecher KN, Anderson CJ: Targeting the alphavbeta3 integrin for small-animal PET/CT of osteolytic bone metastases. J Nucl Med 2009, 50:1873-1880

39. Sun SC, Yamaoka S: Activation of NF-kappaB by HTLV-I and implications for cell transformation. Oncogene 2005, 24:5952-5964

40. Grassmann R, Berchtold S, Radant I, Alt M, Fleckenstein B, Sodroski JG, Haseltine WA, Ramstedt U: Role of human T-cell leukemia virus type $1 \mathrm{X}$ region proteins in immortalization of primary human lymphocytes in culture. J Virol 1992, 66:4570-4575

41. Hasegawa H, Sawa H, Lewis MJ, Orba Y, Sheehy N, Yamamoto Y, Ichinohe $\mathrm{T}$, Tsunetsugu-Yokota $\mathrm{Y}$, Katano $\mathrm{H}$, Takahashi $\mathrm{H}$, Matsuda J, Sata T, Kurata T, Nagashima K, Hall WW: Thymusderived leukemia-lymphoma in mice transgenic for the Tax gene of human T-lymphotropic virus type I. Nat Med 2006, 12:466-472

42. Hao X, Fredrickson TN, Chattopadhyay SK, Han W, Qi CF, Wang Z, Ward JM, Hartley JW, Morse HC 3rd: The histopathologic and 
molecular basis for the diagnosis of histiocytic sarcoma and histiocyteassociated lymphoma of mice. Vet Pathol 2010, 47:434-445

43. Lee SH, Starkey PM, Gordon S: Quantitative analysis of total macrophage content in adult mouse tissues. Immunochemical studies with monoclonal antibody F4/80. J Exp Med 1985, 161:475-489

44. Ohsugi T, Wakamiya M, Morikawa S, Matsuura K, Kumar JM, Kumasaka T, Yamaguchi K: Invasion of histiocytic sarcoma into the spinal cord of HTLV-1 Tax transgenic mice with HTLV-1-associated myelopathy/tropical spastic paraparesis-like disease. Oncol Res 2013, 20:403-410

45. Ward JM, Sheldon W: Expression of mononuclear phagocyte antigens in histiocytic sarcoma of mice. Vet Pathol 1993, 30: $560-565$

46. Ward JM, Quander R, Devor D, Wenk ML, Spangler EF: Pathology of aging female SENCAR mice used as controls in skin two-stage carcinogenesis studies. Environ Health Perspect 1986, 68:81-89

47. Kim WJ, Kim H, Suk K, Lee WH: Macrophages express granzyme B in the lesion areas of atherosclerosis and rheumatoid arthritis. Immunol Lett 2007, 111:57-65

48. Pardo J, Wallich R, Ebnet K, Iden S, Zentgraf H, Martin P, Ekiciler A, Prins A, Mullbacher A, Huber M, Simon MM: Granzyme B is expressed in mouse mast cells in vivo and in vitro and causes delayed cell death independent of perforin. Cell Death Differ 2007, 14:1768-1779

49. Rissoan MC, Duhen T, Bridon JM, Bendriss-Vermare N, Peronne C, de Saint Vis B, Briere F, Bates EE: Subtractive hybridization reveals the expression of immunoglobulin-like transcript 7, Eph-B1, granzyme B, and 3 novel transcripts in human plasmacytoid dendritic cells. Blood 2002, 100:3295-3303

50. Tschopp CM, Spiegl N, Didichenko S, Lutmann W, Julius P, Virchow JC, Hack CE, Dahinden CA, Granzyme B: A novel mediator of allergic inflammation: its induction and release in blood basophils and human asthma. Blood 2006, 108:2290-2299

51. Ohsugi T, Kumasaka T, Okada S, Urano T: The Tax protein of HTLV-1 promotes oncogenesis in not only immature $\mathrm{T}$ cells but also mature T cells. Nat Med 2007, 13:527-528

52. Iwakura Y, Tosu M, Yoshida E, Takiguchi M, Sato K, Kitajima I, Nishioka K, Yamamoto K, Takeda T, Hatanaka M, Yamamoto H, Sekiguchi T: Induction of inflammatory arthropathy resembling rheumatoid arthritis in mice transgenic for HTLV-I. Science 1991, 253:1026-1028

53. Atarashi K, Yoshimura N, Nodera H, Tsukimoto K, Beppu H, Kanayama M: Recurrent histiocytic necrotizing lymphadenitis (Kikuchi's disease) in an human T lymphotropic virus type I carrier. Intern Med 1996, 35:821-825

54. Bataille V, Harland CC, Behrens J, Cook MG, Holden CA: Kikuchi disease (histiocytic necrotizing lymphadenitis) in association with HTLV1. Br J Dermatol 1997, 136:610-612

55. Lee JW, Fox EP, Rodgers-Johnson P, Gibbs CJ Jr, DeFreitas E, Manns A, Blattner W, Cotelingam J, Piccardo P, Mora C, Safar J, Liberski P, Sausville E, Trepel J, Kramer BS: T-cell lymphoma, tropical spastic paraparesis, and malignant fibrous histiocytoma in a patient with human T-cell lymphotropic virus, type 1. Ann Intern Med 1989, 110:239-241

56. Jain P, Ahuja J, Khan ZK, Shimizu S, Meucci O, Jennings SR, Wigdahl B: Modulation of dendritic cell maturation and function by the Tax protein of human T cell leukemia virus type 1. J Leukoc Biol 2007, 82:44-56

57. Ishiguro N, Abe M, Seto K, Sakurai H, Ikeda H, Wakisaka A, Togashi T, Tateno M, Yoshiki T: A rat model of human T lymphocyte virus type I (HTLV-I) infection. 1. Humoral antibody response, provirus integration, and HTLV-I-associated myelopathy/tropical spastic paraparesis-like myelopathy in seronegative HTLV-I carrier rats. J Exp Med 1992, 176:981-989

58. Tanaka M, Nitta T, Yoshida T, Konishi T, Kawazu Y, Fujisawa J, Miwa M: Clonal proliferation of HTLV-1-infected cells is associated with spontaneous malignant tumor formation in mice. Int $\mathrm{J}$ Oncol 2009, 35:701-707
59. Rauch D, Gross S, Harding J, Bokhari S, Niewiesk S, Lairmore M, Piwnica-Worms D, Ratner L: T-cell activation promotes tumorigenesis in inflammation-associated cancer. Retrovirology 2009, 6: 116

60. Nadella MV, Shu ST, Dirksen WP, Thudi NK, Nadella KS, Fernandez SA, Lairmore MD, Green PL, Rosol TJ: Expression of parathyroid hormone-related protein during immortalization of human peripheral blood mononuclear cells by HTLV-1: implications for transformation. Retrovirology 2008, 5:46

61. Shu ST, Martin CK, Thudi NK, Dirksen WP, Rosol TJ: Osteolytic bone resorption in adult T-cell leukemia/lymphoma. Leuk Lymphoma 2010, 51:702-714

62. Kohart NA, Elshafae SM, Supsahvad W, Alasonyalilar-Demirer A, Panfil AR, Xiang J, Dirksen WP, Veis DJ, Green PL, Weilbaecher KN, Rosol TJ: Mouse model recapitulates the phenotypic heterogeneity of human adult T-cell leukemia/lymphoma in bone. J Bone Oncol 2019, 19:100257

63. Shu ST, Dirksen WP, Lanigan LG, Martin CK, Thudi NK, Werbeck JL, Fernandez SA, Hildreth BE 3rd, Rosol TJ: Effects of parathyroid hormone-related protein and macrophage inflammatory protein-1alpha in Jurkat T-cells on tumor formation in vivo and expression of apoptosis regulatory genes in vitro. Leuk Lymphoma 2012, 53:688-698

64. Soda Y, Jinno A, Tanaka Y, Akagi T, Shimotohno K, Hoshino H: Rapid tumor formation and development of neutrophilia and splenomegaly in nude mice transplanted with human cells expressing human T cell leukemia virus type I or Tax1. Leukemia 2000, 14:1467-1476

65. Nerenberg M, Hinrichs SH, Reynolds RK, Khoury G, Jay G: The tat gene of human T-lymphotropic virus type 1 induces mesenchymal tumors in transgenic mice. Science 1987, 237:1324-1329

66. Grossman WJ, Ratner L: Cytokine expression and tumorigenicity of large granular lymphocytic leukemia cells from mice transgenic for the TAX gene of human T-cell leukemia virus type I. Blood 1997, 90: 783-794

67. Kohart NA, Elshafae SM, Demirer AA, Dirksen WP, Breitbach JT, Shu ST, Xiang J, Weilbaecher KN, Rosol TJ: Parathyroid hormonerelated protein promotes bone loss in T-cell leukemia as well as in solid tumors. Leuk Lymphoma 2020, 61:409-419

68. Bunn PA Jr, Schechter GP, Jaffe E, Blayney D, Young RC, Matthews MJ, Blattner W, Broder S, Robert-Guroff M, Gallo RC: Clinical course of retrovirus-associated adult T-cell lymphoma in the United States. N Engl J Med 1983, 309:257-264

69. Rosol TJ, Capen CC: Mechanisms of cancer-induced hypercalcemia. Lab Invest 1992, 67:680-702

70. Nadella MV, Dirksen WP, Nadella KS, Shu S, Cheng AS, Morgenstern JA, Richard V, Fernandez SA, Huang TH, Guttridge D, Rosol TJ: Transcriptional regulation of parathyroid hormone-related protein promoter P2 by NF-kappaB in adult T-cell leukemia/lymphoma. Leukemia 2007, 21:1752-1762

71. Azevedo A, Cunha V, Teixeira AL, Medeiros R: IL-6/IL-6R as a potential key signaling pathway in prostate cancer development. World J Clin Oncol 2011, 2:384-396

72. Studebaker AW, Storci G, Werbeck JL, Sansone P, Sasser AK, Tavolari S, Huang T, Chan MW, Marini FC, Rosol TJ, Bonafe M, Hall BM: Fibroblasts isolated from common sites of breast cancer metastasis enhance cancer cell growth rates and invasiveness in an interleukin-6-dependent manner. Cancer Res 2008, 68:9087-9095

73. Kawano M, Hirano $T$, Matsuda $T$, Taga $T$, Horii $Y$, Iwato $K$, Asaoku H, Tang B, Tanabe O, Tanaka H, Kuramoto A, Kishimoto T: Autocrine generation and requirement of BSF-2/IL-6 for human multiple myelomas. Nature 1988, 332:83-85

74. Li J, Karaplis AC, Huang DC, Siegel PM, Camirand A, Yang XF, Muller WJ, Kremer R: PTHrP drives breast tumor initiation, progression, and metastasis in mice and is a potential therapy target. J Clin Invest 2011, 121:4655-4669

75. Martin CK, Dirksen WP, Shu ST, Werbeck JL, Thudi NK, Yamaguchi M, Wolfe TD, Heller KN, Rosol TJ: Characterization of 
bone resorption in novel in vitro and in vivo models of oral squamous cell carcinoma. Oral Oncol 2012, 48:491-499

76. Downs TM, Burton DW, Araiza FL, Hastings RH, Deftos LJ: PTHrP stimulates prostate cancer cell growth and upregulates aldo-keto reductase 1C3. Cancer Lett 2011, 306:52-59

77. Matsuzaki K, Katayama K, Takahashi Y, Nakamura I, Udagawa N, Tsurukai T, Nishinakamura R, Toyama Y, Yabe Y, Hori M, Takahashi N, Suda T: Human osteoclast-like cells are formed from peripheral blood mononuclear cells in a coculture with SaOS-2 cells transfected with the parathyroid hormone (PTH)/PTH-related protein receptor gene. Endocrinology 1999, 140:925-932
78. Jimi E, Nakamura I, Duong LT, Ikebe T, Takahashi N, Rodan GA, Suda T: Interleukin 1 induces multinucleation and bone-resorbing activity of osteoclasts in the absence of osteoblasts/stromal cells. Exp Cell Res 1999, 247:84-93

79. Frith CH, Suber RL, Umholtz R: Hematologic and clinical chemistry findings in control BALB/c and C57BL/6 mice. Lab Anim Sci 1980, 30: 835-840

80. Hirbe AC, Roelofs AJ, Floyd DH, Deng H, Becker SN, Lanigan LG, Apicelli AJ, Xu Z, Prior JL, Eagleton MC, Piwnica-Worms D, Rogers MJ, Weilbaecher K: The bisphosphonate zoledronic acid decreases tumor growth in bone in mice with defective osteoclasts. Bone 2009, 44:908-916 